\section{Barbara Strzałkowska}

UKSW, Warszawa

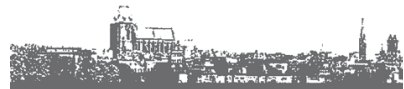

Biblica

et

Patristica

Thoruniensia

ISSN 1689-5150

\title{
Żona Hioba - różne oblicza tej samej kobiety. Interpretacja Hi 2,9-10 w BH i LXX oraz wątek żony w Testamencie Hioba
}

\section{Job's Wife - Different Faces of the Same Woman. The Interpretation of Job 2:9-10 in the Hebrew Bible, the Septuagint and the Testament of Job}

Słowa klucze: Księga Hioba; Septuaginta; Grecka Biblia; Testament Hioba; żona Hioba; Hi 2,9-10.

Key words: the Book of Job; Septuagint; Greek Bible; Septuagint of Job; Testament of Job; Job's Wife; Job 2:9-10.

Streszczenie. Artykuł skupia się na figurze żony Hioba w trzech różnych tradycjach. Rozpoczynając od tekstu hebrajskiego Księgi Hioba, pokazuje różne stadia w interpretacji charakteru żony Hioba i jej roli w księdze. W tekście hebrajskim żona Hioba pojawia się tylko w Hi 2,9-10, gdzie wypowiada jedną sentencję („przeklinaj Boga i umieraj”). Jest ona prezentowana tam jako rodzaj „pomocnicy złego” (diavoli adiutrix), jak była nazwana przez św. Augustyna. Jednak, najstarszy przekład tekstu - grecka Septuaginta (LXX) - pokazuje jej rolę w księdze w odmienny sposób: LXX rozciąga jej mowę aż na parę wierszy, zwracając uwagę nie tylko na cierpienie Hioba, ale także na smutek jego żony, która cierpi jak jej mąż (w szczególności z powodu utraty swoich dzieci i swojej ciężkiej pracy). W oparciu o te interpretację, która $\mathrm{z}$ wielkim prawdopodobieństwem jest dziełem tłumacza Księgi Hioba (oryginalny wariant LXX), wyrasta jeszcze bardziej opracowany obraz żony Hioba w apokryficznym „Testamencie Hioba”, który został stworzony w środowisku starożytnej Aleksandrii (tym samym jak LXX), prawdopodobnie w I w. przed Chr. Charakter i rola żony Hioba, która otrzymuje nawet imię Sitis, rozciąga się na kilka rozdziałów. Jej zachowanie wobec cierpienia męża może być porównane do zachowania kobiet proszących, które w tradycji mądrościowej są ukazane jako odważne (na przykład w poemacie z Prz 31). W ten sposób rozszerzony wątek może być uważany za najstarszą interpretację tekstu Księgi Hioba w wersji LXX. Trzy przedstawione interpretacje należycie prezentują trzy różne twarze tej samej kobiety i są dobrym przykładem wpływu, jaki grecki przekład LXX wywierał na historię interpretacji Księgi Hioba. 
Abstract. The article focuses on the figure of Job's wife in three different traditions. Starting from the Hebrew text of the Book of Job, it shows the different stages in the interpretation of the character of Job's wife and its role in the Book. In the Hebrew text Job's wife appears only in the verses 2:9-10, where she pronounces one sentence ("curse God and die"). She is presented there as a kind of "devil's helper", diavoli adiutrix, as she was called by St. Augustine. However, the oldest translation of the text - the Greek Septuagint - shows her role in the Book differently: LXX extends her speech into couple of verses, paying attention not only to Job's suffering but also to the affliction of his wife, who suffers like her husband (in particular because of the loss of her children and her hard work). On the basis of this interpretation, which in all probability was the work of the LXX translator of the Book of Job (original LXX variant), grew even more elaborate view of Job's wife in the apocryphal Testament of Job, which was created in the environment of ancient Alexandria (thus the same as the Septuagint), probably in the I century BC. The character and role of Job's wife, who even receives a name Sitis, expands to several chapters there. Her attitude toward suffering husband is considered almost like of the women who are praised in the Wisdom tradition as the courageous ones (for example in the poem from Proverbs 31). Such an extended thread can be considered as the oldest interpretation of the LXX text of the Book of Job. These three interpretations due to reveal different faces of the same woman and are the good example of the influence that the Greek translation of the LXX had on the history of interpretation of the Book of Job.

$\ddot{2}$ ona Hioba to postać, która przez wieki interpretacji Księgi Hioba budziła wiele emocji, choć nie jest postacią pierwszoplanową i pojawia się w całej Księdze tylko raz, w ww. 2,9-10, stanowiących część Prologu Księgi. Nie znamy stamtąd szerzej jej historii ani nawet jej imienia, wiemy jedynie, że wypowiada ona jedno krótkie zdanie $(2,9)$, które stało się przedmiotem wielu komentarzy, stawiających ją w szeregu plag i nieszczęść, jakie spadły na jej cierpiącego męża, Hioba. A. Tronina w najnowszym polskim komentarzu do Księgi Hioba napisał, że „słowa żony stanowią przedostatnią próbę wiary męża Bożego" ${ }^{1}$. Próbę, z której Hiob, warto dodać, wyszedł zwycięsko $(2,10)$. Poza kontekstem tych dwóch wersetów żona Hioba już w Księdze się nie pojawia, nawet w Epilogu Księgi, gdzie Hiobowi rodzą się nowe dzieci (nie wiadomo, czy z tej samej żony?). Z tego powodu przyzwyczajono się patrzeć na postać żony przez pryzmat tego krótkiego epizodu z Prologu. Stała się ona jednym z bohaterów negatywnych Księgi, synonimem diaboli adiutrix („pomocnicy, mimowolnej sojusznicy diabła”), jak ją określił św. Augustyn²,

1 A. Tronina, Księga Hioba, Nowy Komentarz Biblijny. Stary Testament XV, Częstochowa 2013, s. 110.

2 Por. np.: N.C. Habel, The Book of Job. A Commentary, Philadelphia 1985, s. 96; zob. także: G. Ravasi, Hiob. Dramat Boga i człowieka, cz. 2, tłum. K. Stopa, Kraków 2005, s. 46. 
czy organum Satanae, jak nazwał ją Kalwin ${ }^{3}$. Taką negatywną ocenę postawy żony odzwierciedlało wiele starożytnych interpretacji ${ }^{4}$, według których żona Hioba, którą porównywano do biblijnej Ewy ${ }^{5}$, miała być - zgodnie z określeniem Jana Chryzostoma - „najgorszą raną Hioba”6. Obecnie poświęca się tej postaci sporo uwagi w komentarzach, a także w publikacjach naukowych ${ }^{7}$

Na temat recepcji tych słów Augustyna zob.: S. Schroer, C. Maier, Das Buch Ijob. Kompendium Feministische Bibelauslegung, Gütersloh 1998, s. 192-207 (zwł. 201n).

3 D.J.A. Clines, Job 1-20, Word Biblical Commentary 17, Nashville 1989, s. 51.

$4 \mathrm{Na}$ ich temat zob. np. ciekawe opracowanie: T. Klibengajtis, Hiobs Weib in der Exegese der lateinischen Kirchenväter. Ein Beitrag zur patristichen Frauenforschung, Analecta Cracoviensia 38-39 (2006-2007), s. 195-229.

5 Tak czynił Jan Chryzostom, Didymos czy Olimpiodor; por. M. Kepper, M. Witte, Job/Das Buch Ijob/Hiob, w: Septuaginta Deutsch. Erläuterungen und Kommentare zum griechischen Alten Testament. Band II: Psalmen bis Daniel, red. M. Karrer, W. Kraus, et alii, Stuttgart 2011, s. 2071.

6 G. Ravasi, Hiob. Dramat Boga i człowieka, cz. 2, s. 46. Na temat interpretacji tej postaci u Jana Chryzostoma zob. zwłaszcza: C. Broc, La femme de Job dans la prédication de Jean Chrysostome, w: Studia Patristica t. XXXVII, red. M.F. Wiles, Leuven 2001, s. 396-403, a o Księdze Hioba u Jana Chryzostoma zob. także: M. Cimosa, John Chrysostom and the Septuagint (Job and Psalms), w: XII Congress of the International Organization for Septuagint and Cognate Studies, Leiden 2004, red. M.K.H. Peters, Septuagint and Cognate Studies Series 54, Atlanta 2006, s. 117-130.

7 Zob. np.: R.F. Bevan, Job ii. 9, Expository Times, 19/1908, s. 190-191; A. Bonus, Job ii. 9, Expository Times, 19/1908, s. 283-284; N. Peters: Zum Charakter der Frau Jobs [Job 2,9s], Theologie und Glaube 11/1919, s. 418-423; D.J. O'Connor, "Bless God and Die" (Job 2:9): Euphemism or Irony? Proceedings of the Irish Biblical Association 19/1996, s. 48-65; V. Sasson, The Literary and Theological Function of Job's Wife in the Book of Job, Biblica 79/1998, s. 86-90 ; C. Matthews McGinnis, Playing the Devil's Advocate in Job: On Job's Wife, w: The Whirlwind, red. S.L. Cook, Sheffield 2001, s. 121-141; E.L. Greenstein, [w języku hebrajskim] [Żona Hioba: czy miała rację?], Beit Mikra, 178(2004)APR-JUN, s. 19-31; Ł. Toboła, "Curse God and die"? A reconsideration of " $m t$ " in Job 2,9b (MT), w: Ethos and exegesis, red. A. Kucz, A. Malina, Studia i Materiały Wydziału Teologicznego Uniwersytetu Śląskiego w Katowicach, nr 41, Katowice 2007, s. 148-151. Por. także m.in. na temat tego tekstu $\mathrm{w}$ tradycji targumicznej: C. Mangan, The Attitude to Women in the Prologue of Targum Job, w: Targumic and Cognate Studies, red. M. McNamara, Sheffield 1996, s. 100-110. Wśród publikacji mówiących o żonie Hioba wiele nawiązuje do feministycznej lektury Pisma Świętego i jej badań, dokładne studium podejścia feministycznego to tego tekstu zob.: G.O. West, Hearing Job's Wife: Towards a Feminist Reading of Job, Old Testament Essays 4/1991, s. 107-131; R.F. Magdalene, Job's Wife as Hero: A Feminist-Forensic Reading of the Book of Job, Biblical Interpretation 14/2006, s. 209-258. Wiele publikacji nawiązuje także do dzieł sztuki, które często przedstawiały scenę spotkania cierpiącego Hioba ze swoją żoną, np.: Z. Gitay, The Portrayal of Job's Wife and Her Representation in the Visual Arts, w: Fortunate the Eyes That See, red. D.N. Freedman, Grand Rapids 1995, s. 516-526; 
i popularnych ${ }^{8}$, próbując coraz lepiej zrozumieć jej rolę w analizowanej tutaj Księdze.

Jednym z ciekawszych wątków związanych z żoną Hioba jest zmiana jej wizerunku, jaka pojawiła się wraz z najstarszym przekładem Księgi Hioba, zawartym w greckiej Septuagincie, gdzie postać żony wydaje się inna, a ocena jej postawy jakby mniej jednoznaczna. Jednozdaniowe wystąpienie bohaterki z BH zostało bowiem w LXX rozbudowane do kilku wersetów, które trochę dokładniej naświetlają jej wypowiedź. Tekst o żonie Hioba zawarty w LXX to wyjątkowo ciekawy przykład zmiany i interpretacji, w i tak bardzo oryginalnym i specyficznym tekście LXX Hi. Dlaczego wypowiedź żony z jednego zdania w tekście hebrajskim, rozbudowana jest do wielu w greckim? Jaki charakter ma ten dodatek w LXX? I czy dodał go sam tłumacz LXX, czy też fragment ten jest efektem późniejszej jego rewizji? I jaki wpływ wywarł ten przekład na rozumienie postaci żony Hioba w dziejach egzegezy? Tradycja aleksandryjska, gdzie powstał ów grecki przekład, znajdzie później jeszcze dalej idące rozwinięcie tego nowego obrazu żony Hioba w apokryficznym tekście Testamentu Hioba. Dzięki tym trzem tradycjom można powiedzieć, że żona Hioba zyskuje jakby nowe oblicza.

\section{Tekst i przekład Hi 2,9-10 w BH i LXX}

Kontekst wypowiedzi żony Hioba, zarówno w tekście hebrajskim, jak i greckim, jest klarowny: szerokim kontekstem jest Prolog do Księgi (Hi 1-2). Napisany prozą, prezentuje sytuację tytułowego bohatera, który będąc „mężem sprawiedliwym, prawym, bogobojnym i unikającym zła" $(1,1)$ doświadcza prób, które na niego spadają. Sceny przedstawione w Prologu dzieją się niejako na dwóch poziomach: tym na ziemi, gdzie Hiob przedstawiony jest jako nie tylko najbardziej prawy, ale i bardzo majętny człowiek, posiadający szczęśliwą rodzinę, który powoli po kolejnych plagach, jakie na niego spadają, traci majętność, dzieci, a w końcu własne zdrowie; oraz w niebie, przed tronem Bożym, gdzie ma miejsce swoista narada, na którą przybywa szatan podpuszczając, by wystawić wiernego czciciela Boga na próbę. O wydarzeniach na obu poziomach wie jedynie czytelnik Księgi. Hiob i inni bohaterowie (także jego żona), znają

A. Schindler, One Who Has Borne Most: The Cri de Coeur of Job's Wife, Australian Biblical Review, 54/2006, s. 24-36.

8 Najlepszym przykładem może być książka zatytułowana Żona Hioba, której autorką jest Andrée Chedid (przekł. P. Sykut, Pelplin 2010). Zob. także: D. J. O’Connor, Job: His wife, his friends, and his God, Maynooth Bicentenary Series, New York 1995. 
tylko ten „ziemski” wątek historii, nie rozumiejąc dlaczego spadają na Hioba kolejne próby. Zgodnie z zasadą retrybucji i ówczesną mentalnością, bohaterowie znajdują się w swoistej konfuzji, która staje się podstawą snucia całej treści Księgi: dlaczego Hioba, który był „najbardziej sprawiedliwy z synów ludzkich” dotknęły nieszczęścia zamiast błogosławieństw? I jak Hiob, mimo nich, pozostaje wierny Bogu, wychodząc obronną ręką z kolejnych prób proponowanych przez szatana.

Wypowiedź żony Hioba, pojawia się na samym końcu Prologu, po tym jak opisane zostały już wszystkie próby, które dotykały jej męża. Po utracie majątku, dzieci, a w końcu zdrowia i czystości (gdy Hiob zapada na nieczystą chorobę trądu; która wyłączyła go ze społeczności i zmusiła do odosobnienia), tekst wprowadza na scenę wypowiedź jego żony, która jawi się jako ostatnia próba, której poddany jest Hiob, i to próba najbardziej dotkliwa - bo od najbliższej osoby. Właśnie w tym momencie, kiedy cierpienie Hioba osiąga swoiste apogeum, przybywa do niego żona, mówiąc te dość ostre (a w tekście greckim nieco bardziej rozbudowane, ale równie gorzkie) słowa. Już po wszystkich próbach, niejako dokłada Hiobowi jeszcze coś od siebie. Niektórzy badacze (jak T.K. Cheyne ${ }^{9}$ ), podkreślali wręcz, że żona nie została zgładzona wraz z dziećmi i całym domem Hioba, po to, by mogła odegrać swoją rolę, jednoznacznie interpretując ją jako negatywną. Jak to określił jeden z komentatorów: „do cierpiącego sprawiedliwego przychodzi namolna żona, przedstawiona tu negatywnie, zgodnie z tradycyjną mizoginią mądrościową (Prz 5,7)"10.

W tekście hebrajskim żona nie jest zapowiedziana jakąśs specjalną formułą, nie naświetla się głębiej jej sytuacji, ale wprowadza się jej postać poprzez użycie

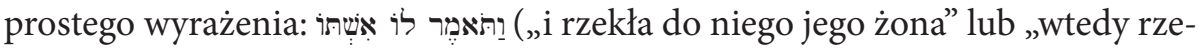
kła do niego jego żona"). W tekście greckim będzie to wyglądało nieco inaczej, ale o tym później. Sam tekst wypowiedzi żony $(2,9)$ także w BH jest krótki, a odpowiedź Hioba $(2,10)$ dosadna. Wątek żony zostaje urwany podsumowaniem narratora, który mówi, że Hiob „w tym wszystkim nie zgrzeszył przeciw Bogu” $(2,10)$, a następnie pojawiają się jego przyjaciele i zaczyna się poetycka część Księgi.

9 T.K. Cheyne cytowany za R. Gordis, The Book of Job. Commentary, New Translation and Special Studies, Moreshet Series, Studies in Jewish History, Literature and Thought 2, New York 1978, s. 21.

10 G. Ravasi, Hiob. Dramat Boga i człowieka, cz. 2, s. 46. 
Ta krótka wypowiedź żony z 2,9 w obu tekstach ${ }^{11}$ brzmi następująco ${ }^{12}$ :

\begin{tabular}{|c|c|c|c|}
\hline \multicolumn{2}{|c|}{ LXX } & \multicolumn{2}{|c|}{ TM } \\
\hline 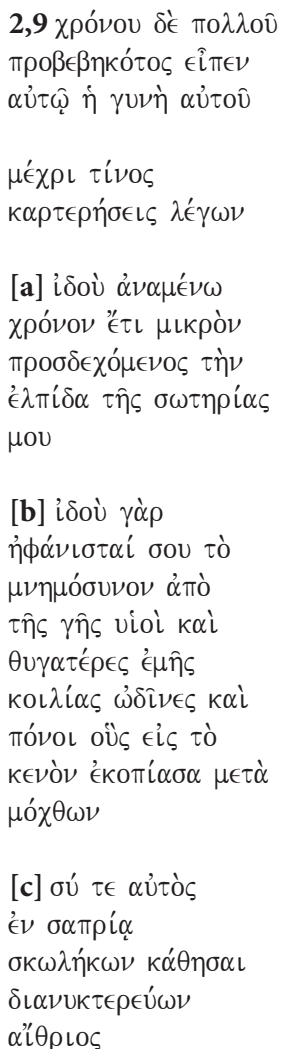 & $\begin{array}{l}\text { 2,9 Kiedy minęło wiele } \\
\text { czasu powiedziała mu } \\
\text { [=Hiobowi] jego żona: } \\
\text { „Jak długo będziesz } \\
\text { trwał, mówiąc: } \\
\text { [a] «Oto poczekam } \\
\text { jeszcze trochę czasu, } \\
\text { oczekując nadziei } \\
\text { mojego wybawienia»? } \\
\text { [b] Oto bowiem został } \\
\text { zniszczony znak } \\
\text { pamięci o Tobie na } \\
\text { ziemi: synowie i córki, } \\
\text { bóle mojego łona, } \\
\text { i trudy, które na próżno } \\
\text { znosiłam w znoju; } \\
\end{array}$ & $\begin{array}{l}\text { 2,9 Wtedy rzekła } \\
\text { do niego [=Hioba] } \\
\text { jego żona: } \\
\text { "Ciągle trwasz } \\
\text { w swojej } \\
\text { prawości... }\end{array}$ & 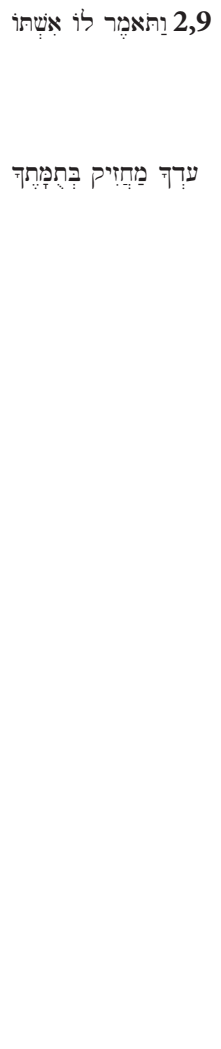 \\
\hline
\end{tabular}

11 Tekst hebrajski podany jest za wydaniem krytycznym BHS (Biblia Hebraica Stuttgartensia, red. K. Elliger, W. Rudolf, Stuttgart $1997^{5}$ ), ale konsultowany o BHK (Biblia Hebraica, red. R. Kittel, P. Kahle (curavit), Stuttgart 19494); tekst grecki zaś za wydaniem krytycznym J. Zieglera z serii z Göttingen (Septuaginta. Vetus Testamentum Graecum. Auctoritate Academiae Scientiarum Gottingensis editum, t. XI, 4 Iob, red. J. Ziegler, Göttingen 1982), ale konsultowany z wydaniami A. Rahlfsa i R. Hanharta (Septuainta. Id est Vetus Testamentum graece iuxta LXX interpretes, red. A. Rahlfs, R. Hanhart, Stuttgart 2006; wyd. 2, poprawione) oraz H.B. Swetego (The Old Testament in Greek According to the Septuagint, t. II: 1 Chronicles-Tobit, red. H.B. Swete, Cambridge 1922 ${ }^{3}$ ). Na temat tekstu LXX Hi zob. także: dokładne studium J. Ziegler, Beiträge zum griechischen Iob, Abhandlungen der Akademie der Wissenschaften in Göttingen. Philologisch-Historische Klasse Dritte Folge 147, Vandenhoeck \& Ruprecht, Göttingen 1985.

12 W polskich przekładach obu wersji różnice między istniejącymi tekstami wyróżnia podkreślenie, natomiast kursywą zaznaczono teksty dodane w LXX, nieobecne w hebrajskim pierwowzorze. 
Ciąg dalszy zestawienia

\begin{tabular}{|c|c|c|c|}
\hline \multicolumn{2}{|c|}{ LXX } & \multicolumn{2}{|c|}{ TM } \\
\hline 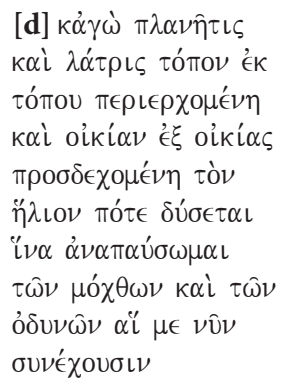 & $\begin{array}{l}\text { [d] A ja jestem tą, } \\
\text { która się btąka, } \\
\text { i stużaca, błądzaca } \\
\text { z miejsca na miejsce } \\
\text { i od domu do domu, } \\
\text { oczekująca kiedy słońce } \\
\text { zajdzie, aby odpoczać } \\
\text { od trudu i udręk, które } \\
\text { mnie teraz nękają. }\end{array}$ & & 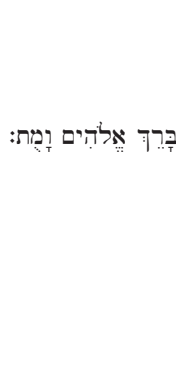 \\
\hline 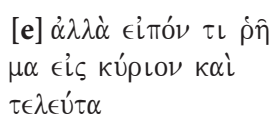 & $\begin{array}{l}\text { [e] Ale powiedz jakieś } \\
\underline{\text { słowo przed Panem }}^{\star}, \\
\text { i umieraj". }\end{array}$ & $\begin{array}{l}\text { Złorzecz (dosł. } \\
\underline{\text { błogosław) Bogu }} \\
\text { i umieraj!” }\end{array}$ & \\
\hline
\end{tabular}

* Także: „przeciw Panu”; na temat obu zob.: M. Kepper, M. Witte, Job/Das Buch Ijob/ Hiob, w: Septuaginta Deutsch. Erläuterungen und Kommentare zum griechischen Alten Testament. Band II: Psalmen bis Daniel, red. M. Karrer, W. Kraus, et alii, Stuttgart 2011, s. 2072.

Inne polskie przekłady tego tekstu są autorstwa W. Linkego ${ }^{13}$ oraz A. Troniny ${ }^{14}$.

13 „Gdy się bardzo postarzał, powiedziała do niego jego żona: «Jak długo będziesz trwał, mówiąc: Oto [po]czekam jeszcze przez krótki czas, oczekując nadziei mojego zbawienia. Oto bowiem został zburzony z ziemi znak pamięci o tobie, synowie i córki cierpienia i bólu moich wnętrzności, którym na próżno się trudziłam z wysiłkiem. Ty sam zaś w zgniliźnie robaków siedzisz spędzając noc pod gołym niebem. I ja jestem tułaczką i wyrobnicą przechodzącą między miejscem a miejscem, domem a domem, wyczekującą słońca, kiedy zajdzie, abym wypoczęła wśród trudów i żałości, które mnie teraz mocno trzymają. Ale powiedz jakieś słowo przed Panem i umrzyj»." (W. Linke, Testament Hioba, w: Pisma apokaliptyczne i Testamenty, red. M. Parchem, Apokryfy Starego Testamentu pod redakcją Zdzisława J. Kapery i Stanisława Mędali t. 2, Kraków-Mogilany 2010, s. 369, przyp. 205).

14 „A gdy minęło sporo czasu, żona rzekła do niego: Jak długo będziesz tak trwał, mówiąc: Oto poczekam jeszcze trochę, oczekując nadziei mego ocalenia? Bo oto twój dobytek został powalony na ziemię, podobnie synowie twoi i córki, ból i cierpienie mego łona, których na darmo nosiłam w łonie. Ty sam siedzisz, nocując pod gołym niebem pośród cuchnącego robactwa. A ja wędruję po służbie, z miejsca na miejsce, z domu do domu, czekając zachodu słońca, abym mogła odpocząć po trudach i udrękach, które mnie otaczają. Powiedz parę słów przeciw Panu i umieraj!” (A. Tronina, Księga Hioba, Nowy Komentarz Biblijny, s. 587-588). 
Odpowiedź męża $(2,10)$ z kolei brzmi ${ }^{15}$ :

\begin{tabular}{|c|c|c|c|}
\hline \multicolumn{2}{|c|}{ LXX } & \multicolumn{2}{|c|}{ TM } \\
\hline 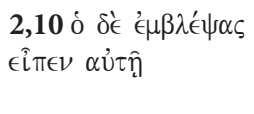 & $\begin{array}{l}\text { 2,10 On zaś [=Hiob] } \\
\text { popatrzywszy, } \\
\text { powiedział jej: }\end{array}$ & $\begin{array}{l}\text { 2,10 Odpowiedział } \\
\text { jej [Hiob]: }\end{array}$ & 2,10 וַיאמֶר אֶליה \\
\hline 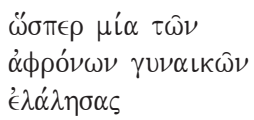 & $\begin{array}{l}\text { „Powiedziałaś jak } \\
\text { jedna z nierozumnych } \\
\text { kobiet. }\end{array}$ & $\begin{array}{l}\text { „Mówisz jak jedna } \\
\text { z głupich. }\end{array}$ & 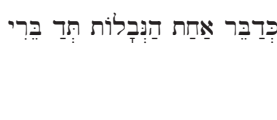 \\
\hline 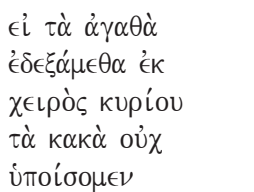 & $\begin{array}{l}\text { Skoro dobre [rzeczy] } \\
\text { przyjęliśmy z ręki } \\
\text { Pana, } \\
\text { [to czy] złych nie } \\
\text { przetrwamy? }\end{array}$ & $\begin{array}{l}\text { Skoro dobro } \\
\text { przyjęliśmy od } \\
\text { Boga, } \\
\text { to zła nie } \\
\text { przyjmiemy?" }\end{array}$ & 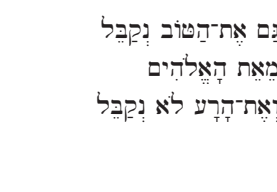 \\
\hline 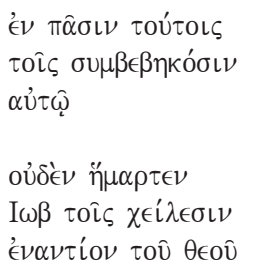 & $\begin{array}{l}\frac{\mathrm{W} \text { tych wszystkich }}{\underline{\text { rzeczach które przyszły }}} \\
\text { na niego } \\
\text { nie zgrzeszył Hiob } \\
\text { wargami przed Panem. }\end{array}$ & $\begin{array}{l}\frac{W \text { tym wszystkim }}{\text { nie zgrzeszył Hiob }} \\
\text { wargami. }\end{array}$ & 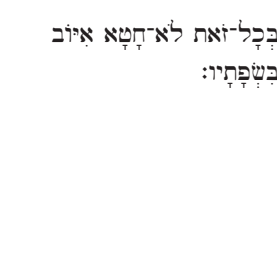 \\
\hline
\end{tabular}

Na pierwszy rzut oka widać w obu tekstach znaczne różnice, choć kontekst wypowiedzi jest w nich podobny. Co ciekawe, żadna z wersji starożytnych nie powtórzy oryginalnej dłuższej lekcji wypowiedzi żony Hioba zawartej w LXX, choć na jej podstawie rozwinie później inne rozumienie postaci żony Testament Hioba.

\section{Interpretacja Hi 2,9-10 w Biblii Hebrajskiej}

Ukazane zostało, że żona Hioba pojawia się w momencie, w którym Hiob, poddany już wszystkim próbom szatana, pozostaje wierny Bogu.

15 Inny polski przekład tego tekstu to ten autorstwa A. Troniny: „Lecz on spojrzał na nią i rzekł jej: Mówiłaś jak jedna z kobiet szalonych. Jeśli otrzymaliśmy dobra z rąk Pana, to czemu nie możemy wycierpieć zła. W tym wszystkim, co go spotkało, Job nie zgrzeszył swymi wargami wobec Pana”. (A. Tronina, Księga Hioba, Nowy Komentarz Biblijny, s. 588). 
W TM żona Hioba mówi do męża tylko jedno zdanie ${ }^{16}$ :

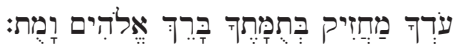

„Ciągle trwasz w swojej prawości... Złorzecz [dosł. „błogosław”; tu w znaczeniu eufemistycznym] Bogu i umieraj!”.

Dokładna analiza tej wypowiedzi ukazuje, że słowa żony Hioba złożone są z dwóch części, stanowiących echa wcześniejszych wypowiedzi obecnych już w Prologu:

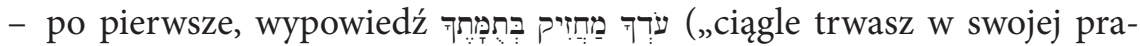
wości”) jest echem słów Boga z w. 2,3 $3^{17}$, kiedy to Bóg, dumny ze swego wiernego sługi, który pozostał wierny mimo spadających na niego prób, wypowiada dokładnie to samo wyrażenie („Rzekł Pan szatanowi: «Zwróciłeś uwagę na sługę mego, Hioba? Bo nie ma na całej ziemi drugiego, kto by był tak prawy, sprawiedliwy, bogobojny i unikający zła jak on. Jeszcze trwa w swej prawości, choć mnie nakłoniłeś do zrujnowania go, na próżno»).

- po drugie - i to częściej podkreślane jest przez komentatorów - wypo-

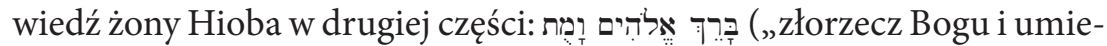
raj”), stanowi wyraźne echo słów szatana $\mathrm{z}$ ww. 1,11 oraz 2,5 - który właśnie w ten sposób chciał, by Hiob zareagował wobec Boga po zesłanych na niego próbach ${ }^{18}$ („Wyciągnij, proszę, rękę i dotknij jego majątku! Na pewno Ci w twarz będzie złorzeczył”; oraz: „Wyciągnij, proszę, rękę i dotknij jego kości i ciała. Na pewno Ci w twarz będzie złorzeczył").

$\mathrm{Z}$ powodu tego drugiego podobieństwa wielu komentatorów podkreślało, że rola żony Hioba polegała na byciu swoistą „tubą szatana” i „adwokatem diabła", jak nazwał ją jeden z komentujących ten fragment ${ }^{19}$.

Cała wypowiedź w ustach żony Hioba w BH brzmi rzeczywiście dość okrutnie, a nawet ironicznie. Już samo wyrażenie „złorzecz Bogu i umieraj”, było różnie interpretowane: bądź jako ironia żony Hioba, bądź jako zawarty

16 Trzeba powiedzieć, że zdanie to przekazane było wiernie, krytyka tekstualna nie podaje innych wariantów tego tekstu w manuskryptach hebrajskich. Masoreci odnotowali jedynie scriptio defectiva przy terminie עירד; por. BHS.

17 Por. np. D.J.A. Clines, Job 1-20, s. 51.

18 Por. np. N.C. Habel, The Book of Job. A Commentary, s. 96.

19 C. Matthews McGinnis, Playing the Devil's Advocate in Job: On Job's Wife, w: The Whirlwind, red. S.L. Cook, Sheffield 2001, s. 121-141. 
w tekście eufemizm ${ }^{20}$. Termin ברך oznacza „błogosławić”, jednak tu należy go odczytywać eufemistycznie właśnie (jako „złorzeczyć”), gdyż taką interpretację tego terminu sugeruje kontekst: zwłaszcza reakcja Hioba z w. 10 - gdyby żona zachęcała go do błogosławieństwa Bogu, nie byłby oburzony i nie została by ona przez niego nazwana niemądrą ${ }^{21}$. Podobnie zresztą użyto to słowo już w omawianym kontekście, w w. 1,522, a także właśnie tak interpretuje go starożytny przekład syryjski, który w miejsce „błogosławić” używa terminu kallel oznaczającego „złorzeczyć”, tak by nie było już żadnych wątpliwości, co do jego interpretacji ${ }^{23}$. Są jednak wersje starożytne, które nie przekładają tego eufemistycznie, a dosłownie: jako błogosławieństwo przekłada ten tekst tradycja targumiczna ${ }^{24}$ i Vulgata („benedic Deo et morere”); można je wówczas odczytać ironicznie.

Cytowany wcześniej badacz, J.E. Hartley, zauważał, że żona Hioba mogła wypowiadać te słowa, obawiając się, że „trwanie w prawości” jej męża nie jest jego cnotą, ale zrodzonym przez okoliczności fanatyzmem ${ }^{25}$, a zarazem ubierając w słowa to, co było jego największą pokusą ${ }^{26}$.

Próbując usprawiedliwić nieco słowa żony Hioba z BH objaśniano je na różny sposób. P. Dhorme wspomina na przykład, że drugi czasownik w formie imperatywnej jest jedynie konsekwencją pierwszego, a całe zdanie należałoby rozumieć jako „złorzecz Bogu przed śmiercią"27. Ł. Toboła z kolei ukazuje, iż zgodnie $\mathrm{z}$ analizą retoryczną tego fragmentu, wypowiedź żony pełni ważną funkcję w paralelnej strukturze Prologu - jest analogiczna do tej, którą pełnili posłannicy, zawiadamiający Hioba o kolejnych nieszczęściach ${ }^{28}$. Ukazuje także inne znaczenie terminu מת, który miałby pochodzić od rdzenia מתת , „łączyć się”

20 Por. choćby: D.J. O’Connor, "Bless God and Die" (Job 2:9): Euphemism or Irony?, Proceedings of the Irish Biblical Association 19/1996, s. 48-65.

21 P. Dhorme, Le Livre de Job, Paris 1926, s. 18.

22 Na temat użycia tego terminu w Prologu Księgi Hioba zob.: T. Linafelt, The Undecidability of $277^{\prime}$ in the Prologue to Job and Beyond, Biblical Interpretation 4/1996, s.154-172; por. także: C. Mangan, Blessing and Cursing in the Prologue of Targum Job, w: Targum and Scripture, red. E.G. Clarke, Leiden 2002, s. 225-229.

23 P. Dhorme, Le Livre de Job, s. 18

24 Por. C. Mangan, The Targum of Job, The Aramaic Bible 15, Collegeville Minnesota 1991, s. 26.

25 J.E. Hartley, The Book of Job, s. 83.

26 Ibidem.

27 P. Dhorme, Le Livre de Job, s. 18; por. D.J.A. Clines, Job 1-20, s. 5.

28 Ł. Toboła, "Curse God and die"? A reconsideration of " $m$ t" in Job 2,9b (MT), w: Ethos and exegesis, red. A. Kucz, A. Malina, Studia i Materiały Wydziału Teologicznego Uniwersytetu Śląskiego w Katowicach, nr 41, Katowice 2007, s. 148. 
(z Bogiem $)^{29}$, a cała wypowiedź żony miałaby zachęcać Hioba do błogosławienia Bogu i połączenia $\mathrm{z} \mathrm{Nim}^{30}$. Jednak taka propozycja, by słowa żony w tekście hebrajskim zinterpretować pozytywnie, pojawiająca się już dawniej w badaniach egzegetycznych, wydaje się trudna do przyjęcia w kontekście odpowiedzi Hioba z 2,10 (nie przekonuje także podana przez autora argumentacja ${ }^{31}$ versus wielowiekowej tradycji interpretacji tego fragmentu).

Podejmowane próby objaśnienia wypowiedzi żony Hioba nie wystarczają, jak się wydaje, by usprawiedliwić jej zachowanie, w formie, w jakiej przekazuje je tekst hebrajski. Najlepszym usprawiedliwieniem może być jedynie to, że Księga Hioba nie przedstawia z jakichś powodów pełnego kontekstu zachowania żony Hioba, jej charakteru, a jedynie na podstawie jej krótkiego wystąpienia ocenia się całość: jej negatywną postawę i brak cierpliwości (skoro nie czekała nawet siedmiu dni, jak przyjaciele Hioba, by wyrazić swoją opinię) ${ }^{32}$, a nade wszystko nie ukazuje, że i ona w całej tej trudnej sytuacji z pewnością cierpiała.

Tak uczyni to w oryginalnej lekcji LXX, dodając do wypowiedzi słowa żony, które rzucą nowe światło na kontekst jej przeżyć i całej sytuacji. Wprawdzie tradycja targumiczna także rozbudowuje krótko tekst (przede wszystkim dodaje ona nieobecne w tekście hebrajskim imię żony Hioba - Dina ${ }^{33}$ : i powiedziała do niego Dina, żona [jego]”, utożsamiając żonę Hioba z bohaterką Rdz 34, Diną córką Jakuba ${ }^{34}$ ), ale nie tak bardzo jak LXX.

Odpowiedź Hioba, jaką daje on swojej żonie w BH $(2,10)$ jest także zwięzła i dość gwałtowna: „Mówisz jak jedna z głupich. Skoro dobro przyjęliśmy od Boga, to zła nie przyjmiemy?” (przy czym użyty tu trudny termin נָָָָ „głupi, nierozsądny" był przedmiotem wielu dyskusji i interpretacji ${ }^{35}$, choć w kontekście omawianej wypowiedzi jest dość jasny). I narrator dodaje: „W tym wszystkim nie zgrzeszył Hiob wargami., jakby chwaląc Hioba za jego postawę wobec

\footnotetext{
29 Ibidem, s. 149.

30 Ibidem, s. 149-150.

31 Ibidem, s. 150-151.

32 N.C. Habel, The Book of Job, s. 96.

33 Por. C. Mangan, The Targum of Job, s. 26; por. także: P. Dhorme, Le Livre de Job, s. 18; niektóre kodeksy targumów jednak pomijają to imię (por. C. Mangan, The Targum of Job,

34 Wątek targumicznej interpretacji imienia jest także ciekawy: imię Dina ma bowiem podkreślać, że dzieje Hioba włączone są w dzieje patriarchów (C. Mangan, The Targum of Job, s. 27), albo też podkreśla jej szaleństwo (podobnych terminów jak Hi 2,9 używa w. Rdz 34,7, opisując szaleństwo Diny; por. P. Dhorme, Le Livre de Job, s. XVII).

35 P. Joüon, Racine נבל au sens de bas, vil, ignoble, Biblica 5/1924, s. 357-361; por. także (wraz z bibliografią) D.J.A. Clines, Job 1-20, s. 54.
} s. 27). 
tej ostatniej pokusy ${ }^{36}$. Odpowiedzi żony nie $\mathrm{ma}^{37}$. Tekst LXX nawet tę wypowiedź ukaże w innym świetle, ale zwłaszcza zmieni tekst wypowiedzi samej żony.

\section{Interpretacja Hi 2,9-10 w Septuagincie. Kontekst LXX Hi}

Zanim zostanie objaśniony sam dodatek dot. żony Hioba w tekście LXX Hi, warto przyjrzeć się specyfice greckiego przekładu tej Księgi. Jest to bowiem bardzo szczególny przypadek w LXX ${ }^{38}$.

Po pierwsze, LXX Hi jest przekładem bardzo zmienionym względem hebrajskiego oryginału, zwłaszcza na tle innych ksiąg. Na ogół jest skrótem tekstu hebrajskiego, ujednoliconym, przepracowanym i dostosowanym do interpretacji, jaką chciał zawarzeć w swoim tekście tłumacz LXX. Tekst ten jest aż o 20\% krótszy ${ }^{39}$ od tekstu hebrajskiego (część stychów, wersetów i większych partii tekstu nie została po prostu przełożona; np. Hi 21,28-33; 26,5-11; 34,28-33; 36,5b-9; 36,29-37,5a i inne), a w częściach, które zostały przełożone tłumacz wprowadził sporo zmian, czasem znaczących. Trzeba powiedzieć pozwalał so-

36 Jedna z rabinicznych interpretacji doda, że Hiob w tym przewyższył Adama, że nie uległ pokusie swojej żony: Midrasz Genesis Rabba 19,12; cyt. za: D.J.A. Clines, Job 1-21, s. 51.

37 Wyjaśniano to mentalnością ukształtowaną przez społeczeńśtwo patriarchalne: D.J.A. Clines, Why Is There a Book of Job, and What Does It to You if You Read It?, w: The Book of Job, red. W.A.M. Beuken, Bibliotheca Ephemeridum Theologicarum Lovaniensium CXIV, Leuven 1994, s. 2-20; por. także: V. Sasson, The Literary and Theological Function of Job's Wife in the Book of Job, s. 86nn.

38 Bibliografia dot. LXX Hi zob.: B. Strzałkowska, Mowy Elihu Mowy Elihu (Hi 32-37) oraz ich reinterpretacja w Biblii Greckiej, Rozprawy i Studia Biblijne 35, Warszawa 2009, s. 650-655; zob. dodatkowo ostatnie publikacje o charakterze ogólnym dotyczące tej Ksiegi w LXX: M. Witte, The Greek Book of Job, w: Das Buch Hiob und seine Interpretationen. Beiträge zum Hiob-Symposium auf dem Monte Verità vom 14.-19. August 2005, Abhandlungen zur Theologie des Alten und Neuen Testaments 88, Zürich 2007, s. 33-53; a także: M. Kepper, M. Witte, Job/Das Buch Ijob/Hiob, w: Septuaginta Deutsch. Erläuterungen und Kommentare zum griechischen Alten Testament. Band II: Psalmen bis Daniel, s. 2041-2126.

39 M. Witte podaje 18\% (por. The Greek Book of Job, w: Das Buch Hiob und seine Interpretationen, s. 34); inni mówią o 1/5 brakujących wersetów (R. Kittel); lub o 1/6 braków (G. Bickell, S.R.Driver i G.B. Gray, H.M. Orlinsky, S. Jellicoe, C.E.Cox); na ten temat, zob. paragraf: Tekst pierwotny LXX Hi i rewizja Orygenesa, w: B. Strzałkowska, Mowy Elihu (Hi 32-37) oraz ich reinterpretacja w Biblii Greckiej, s. 28-41. 
bie w przypadku tej Księgi na daleko posuniętą swobodę. M. Witte nazwie ją "an independent literary work with its own structure and message"40.

Po drugie, przekład, który wyszedł spod pióra tłumacza LXX w Aleksandrii $^{41}$, najprawdopodobniej w poł. II w. przed Chr. ${ }^{42}$, nazywany często „pierwotnym tekstem Księgi Hioba w LXX” (w obszarze języka angielskiego: Old Greek), miał skomplikowane dzieje przekazu. Wiadomo, że został on poddany rewizjom, z których najważniejszej dokonał Orygenes (185-253) ${ }^{43}$, który sam pisał o jej szczegółach w Liście do Juliusza Afrykańczyka oraz w Komentarzu do Ewangelii Mateusza ${ }^{44}$. Mimo problemów z tekstem powstałym w wyniku tej

40 M. Witte, The Greek Book of Job, w: Das Buch Hiob und seine Interpretationen, s. 38.

41 Na temat środowiska powstania przekładu zob. np.: C.E. Cox, The Historical, Social, and Literary Context of Old Greek Job, w: XII Congress of the International Organization for Septuagint and Cognate Studies, Leiden 2004, red. M.K.H. Peters, Septuagint and Cognate Studies Series 54, Atlanta 2006, s. 105-116.

42 Na temat datacji tego przekładu zob. np.: M. Cimosa, La data probabile della traduzione greca (LXX) del Libro di Giobbe, Sacra Doctrina Monografia 51(2006)6, s. 17-35; por. także: G. Gerlemann, Date of the Greek Book of Job, w: Studies in the Septuagint. I: Book of Job, Lund 1946, s. 73-75; U. Pace, I LXX di Giobbe: Metodologia Della Versione Greca e possibilità di datazione attraverso l'analisi delle tecniche di traduzione, Annali della Facoltà di Filosofia e Lettere dell'Università Statale di Milano 45/1992, s. 5-24. Por. także podsumowanie tematu: Datacja pierwotnego tekstu LXX Hi, w: B. Strzałkowska, Mowy Elihu (Hi 32-37) oraz ich reinterpretacja w Biblii Greckiej, s. 42-45.

43 Studia na ten temat zob. choćby: E.M.A. Hatch, On Origen's Revision of the LXX Text of Job, w: idem, Essays in Biblical Greek, The Clarendon Press, Oxford 1889, s. 215-245.

44 Orygenes opisuje, że porównując tekst pierwotny LXX z tekstem hebrajskim i pozostałymi ważnymi przekładami tekstu hebrajskiego na język grecki, które posiadał (chodzi o przekłady Symmacha, Aquili i Teodocjona), uzupełnił brakujące w tym greckim tekście wersety (wspomniane ok. 1/5 tekstu), uzgadniając i harmonizując tekst LXX Hi z jego hebrajskim pierwowzorem. Orygenes wspomina o tym w czwartym punkcie swojego Ė $\pi \hat{i}$

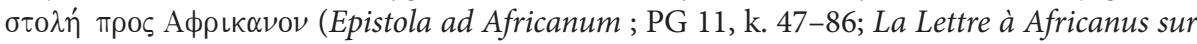
l'histoire de Suzanne, SC, t. 302, s. 469-578), pisząc: „Jeszcze raz jest w całej Księdze Hioba wiele zdań, które można znaleźć u Hebrajczyków, a u nas nie; często zdarza się tak z czterema lub trzema liniami, ale czasem czternastoma, dziewiętnastoma i piętnastoma. Czy jest potrzebne, żebym je dodał do listy? Odnotowałem je z wielkim trudem, by nie być niezorientowanym w różnicy między egzemplarzami żydowskimi i naszymi” (przekład własny; por. B. Strzałkowska, Mowy Elihu (Hi 32-37) oraz ich reinterpretacja w Biblii Greckiej, s. 31-32). Por. także: Orygenes, Commentaria In Evangelium secundum Matthaeum XV,14 (PG 13, k. 1290-1295, zwł. k. 1293; w SC do tomu XV brak; por. także: Origenes, Matthäuserklärung, Origenis Werke, t. X, red. E. Klostermann, Leipzig 1935, s. 387-390. Orygenes uzupełniając mechanicznie tekst, zatracił tym samym szczególny, zmieniony względem hebrajskiego tekstu, charakter Hi w LXX i stworzył w jakimś sensie własny tekst księgi, swoisty „tekst-hybrydę”, który de facto nigdy nie istniał. Uczynił to za tekstem przekładu Teodocjona, który ma bardziej dosłowny charakter niż parafrazujący styl pierwotnego tek- 
rewizji, to właśnie ta Orygenesowa wersja Księgi Hioba, nazywana także czasem „tekstem Kościelnym greckiej Księgi Hioba”, weszła do kodeksów LXX, jako jeden z nielicznych takich przypadków w Biblii! Dlatego też dziś nie posiadamy żadnych manuskryptów zawierających "pierwotny tekst grecki Hi”, możemy go jednak z dużą dozą prawdopodobieństwa odtworzyć. Żeby dokonać porównania tekstu hebrajskiego i greckiego zawartego w LXX, trzeba odtworzyć tekst pozbawiony Orygenesowych dodatków, bo tylko taki może być metodologicznie przedmiotem badań porównawczych ${ }^{45}$. Pomagają w tym manuskrypty (zwł. 2 greckie, 2 łacińskie i Syrohexapla), które zaznaczają każdy uzupełniony werset ${ }^{46}$.

Tekst LXX Hi ma zatem złożoną historię powstania i przekazu oraz stanowi raczej swobodną parafrazę hebrajskiego tekstu niż jego dosłowny przekład. Mimo tej „niedosłowności” tłumaczenia, układa się ono jednak w logiczną i spójną całość w formie, jaka wyszła spod pióra tłumacza. C.E. Cox, ułożył nawet powiedzenie, że ,judaizm dwa razy dał światu Hioba” - raz w tekście hebrajskim, drugi raz w jego greckim tłumaczeniu ${ }^{47}$.

Podobnie, nieco parafrazując to powiedzenie, można powiedzieć, że dwa razy świat otrzymał obraz żony Hioba: raz przekazany w hebrajskim oryginale, a drugi raz - przekazany przez najstarszy przekład hebrajskiego tekstu: Septuagintę. Oba obrazy ukazują ją bowiem w innym świetle.

Przypadek żony Hioba jest w ogóle szczególny w greckiej Księdze Hioba, na tle wszystkich tych różnic między tekstami, które zostały wspomniane ${ }^{48}$.

stu LXX (na ten temat zob. choćby: C. Cox, Origen's Use of Theodotion in the Elihu Speeches, Second Century. A Journal of Early Christian Studies 3/1983, s. 89-98).

45 Por. C.E. Cox., Methodological Issues in the Exegesis of LXX Job, w: VI Congress of the International Organization for Septuagint and Cognate Studies, Jerusalem 1986, red. idem, Septuagint and Cognate Studies Series 23, Scholars Press, Atlanta 1987, s. 79-89.

46 Por. Strzałkowska, Mowy Elihu (Hi 32-37) oraz ich reinterpretacja w Biblii Greckiej, s. 28-41 (zwł. 32-34).

47 C.E. Cox, The Historical, Social, and Literary Context of Old Greek Job, s. 105; por.: B. Strzałkowska, Mowy Elihu (Hi 32-37) oraz ich reinterpretacja w Biblii Greckiej, s. 10.

48 Mimo to, nie ma wielu publikacji poświęconych temu dodatkowi. Badacze, którzy poświęcili wiele pracy na studia braków w LXX Hi (np. P.J. Gentry, The Asterisked Materials in the Greek Job, Septuagint and Cognate Studies Series 38, Atlanta, Georgia 1995 czy M. Gorea, Job repensé ou trahi? Omissions et raccourcis de la Septante, Études Bibliques. Nouvelle Série 56, Paris 2007), pominęli w opracowaniach problem dodatków do Księgi, zapewne dlatego, że są tak nieliczne. Jedynie w kilku miejscach podjęta została próba analizy LXX Hi 2,9. Najnowszym artykułem na ten temat jest: J. Cook, Are the Additions in Job 2,9a-e to Be Deemed as the Old Greek Text? Biblica 91/2010, s. 275-284 oraz M. Witte, Hiob und Seine Frau in jüdischen Schriften aus hellenistische-römischer Zeit, w: H. Lichtenberger, U. Mittmann-Richtert, Biblical Figures in Deuterocanonical and Cognate Literature, Deuterocanonical and Cognate Literature Yearbook 2008, s. 355-394. Zob. także paragraf: The 
Tekst dotyczący żony Hioba przede wszystkim jest dodatkiem do Księgi Hioba względem BH. O ile w większości przypadków tekst grecki w LXX skraca tekst hebrajski, o tyle tu, go wydłuża, dodając nowe watki, nieobecne w hebrajskim pierwowzorze; i jest to jeden z tylko dwóch dużych dodatków do księgi w LXX: tu w 2,9 w wypowiedzi żony oraz na końcu Księgi, w r. 42,17 w tekście rodowodu Hioba ${ }^{49}$ (a obok nich są jeszcze dwa niewielkie dodatki w mowach Elihu: 32,17 oraz $\left.36,28^{50}\right)$.

O ile w TM żona Hioba mówiła jedno zdanie, o tyle w tekście LXX to jedno zdanie rozwinięte zostaje do kilku wersetów tekstu (M. Witte wylicza, że 2 stychy wypowiedzi z BH, rozrastają się do $12 \mathrm{w} \mathrm{LXX}{ }^{51}$ ). Analizując tekst dodatku LXX (tekst i przekład został przedstawiony w tabeli powyżej), już na pierwszy rzut oka widać, że obraz żony Hioba jest tu inny. O ile w tekście hebrajskim, pełniła ona rolę „współpracownika szatana”, dokładającego Hiobowi cierpienia, o tyle tu jej obraz przede wszystkim zwraca uwagę na cierpienie samej żony Hioba, o czym w tekście hebrajskim nie było w ogóle mowy.

Co ciekawe, fragment jej wypowiedzi w LXX zaczyna się od typowej for-

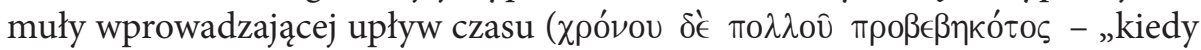
minęło wiele czasu...”). Ta formuła, częściej używana przez autorów klasycznych, w LXX pojawia się poza omawianym tekstem jeszcze tylko w Rdz 18,11 $1^{52}$. Podkreśla ona inne nastawienie żony Hioba, która w tekście hebrajskim zdaje się mówić gwałtownie - tu zdradza jej przeciwne, spokojniejsze, usposobienie:

"Extensions” in the Greek Book of Job, w: idem, The Greek Book of Job, w: Das Buch Hiob und seine Interpretationen, s. 42-46; oraz dawniejszy artykuł: J. Gray, The Additions in the Ancient Greek Version of Job, The Expositor 19/1920, s. 422-438 (mówiący także o tekście z końca Księgi).

49 Na temat tego tekstu, zob. także: M. Witte, The Greek Book of Job, w: Das Buch Hiob und seine Interpretationen, s. 42-46 (paragraf: „Extensions” in the Greek Book of Job); oraz: A.Y. Reed, Job as Jobab. The Interpretation of Job in LXX Job 42:17b-e, Journal of Biblical Literature 120/2001, s. 31-55; M. Wojciechowski, Grecki epilog Ksiegi Hioba i Arysteasz Egzegeta, w: Żywe jest słowo Boże i skuteczne. Księga pamiątkowa dla Ks. Prof. Bernarda Wodeckiego SVD w 50. rocznicę święceń kapłańskich, red. W. Chrostowski, Warszawa 2001, s. 323-331.

50 Pierwszy dodatek zmienia podział tekstu i ma charakter bardziej techniczny, drugi łączy niejako wszystkie brakujące wersety dookoła niego, tworząc ich zwięzłą syntezę. Na ich temat: B. Strzałkowska, Mowy Elihu (Hi 32-37) oraz ich reinterpretacja w Biblii Greckiej, s. 165-173 oraz 525-539.

51 M. Witte, The Greek Book of Job, w: Das Buch Hiob und seine Interpretationen, s. 42.

52 Por. H. Heater Jr., A Septuagint Translation Technique in the Book of Job, The Catholic Biblical Quarterly Monograph Series 11, Washington DC 1982, s. 32. 
minęło wiele czasu zanim żona przemówiła. Pomocą dla uzyskania tego efektu jest właśnie ta formuła, a także użyty w tekście genetivus absolutus ${ }^{53}$.

Ciekawy jest także wątek, który pojawia się zaraz potem; żona pyta Hioba „Jak długo będziesz trwał, mówiąc: «Oto poczekam jeszcze trochę czasu, oczekując nadziei mojego wybawienia»?" Hiob takie słowa o nadziei wybawienia powie dopiero w w. 13,16, w części poetyckiej Księgi. W tekście LXX żona już niejako antycypuje to, co stanie się dopiero za kilka rozdziałów w Księdze ${ }^{54}$. W Prologu Hiob nie mówi przecież nic podobnego. Podobnie, jak uważają niektórzy, ma się rzecz z jego nocnym siedzeniem i robakami, które pojawiają się w wypowiedzi żony Hioba w LXX, w TM zaś pojawią się w skardze Hioba zawartej w r. 7, gdzie właśnie wspomni on i robaki, i noc ${ }^{55}$. Tłumacz zatem (lub redaktor tego tekstu) wypowiedzi żony Hioba w LXX, wykorzystał te motywy, które w samej Księdze pojawią się dopiero później. H. Heater konkluduje zatem, że źródłem dla tego parafrazującego dodatku w Księdze Hioba w LXX musiała być sama treść Księgi Hioba w jej całości ${ }^{56}$. Żona ukazuje, że cierpi dokładnie tak jak Hiob, który na przestrzeni całej Księgi owo cierpienie będzie starał się wyrazić.

Istotne jest właśnie to, że o ile tekst hebrajski, a za nim późniejsze interpretacje, kładły nacisk na rolę żony w kuszeniu Hioba, o tyle tekst grecki zwraca uwagę bardziej na samą żonę Hioba i jej przeżycia. Ale o ile wszyscy skupiają się na Hiobie, o tyle dodatek LXX zwraca uwagę, że przecież całą tą trudną sytuacją (zwłaszcza śmiercią dzieci i utratą majątku) została dotknięta także jego żona. Tekst ukazuje także jej postawę i ciężką pracę po wydarzeniach, jakie na nich spadły („ja jestem tą, która się błąka, i służącą, błądzącą z miejsca na miejsce i od domu do domu, oczekującą kiedy słońce zajdzie, aby odpocząć od trudu i udręk, które mnie teraz nękają"). Scena wypowiedzi żony Hioba w LXX jest bardzo obrazowa. Można sobie wyobrazić Hioba, który załamany siedzi

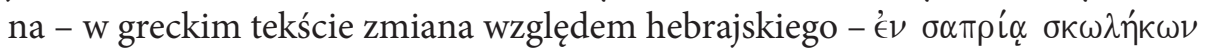
(„zgniliźnie robaków”), a jego żona przejęła wszystkie obowiązki: musi pracować jako niewolnica, by utrzymać siebie i - jak można mniemać - utrzymać też męża (wyrzuconego poza nawias społeczeństwa ze względu na nieczystą chorobę - trąd). Ona, która była wcześniej żoną najbogatszego człowieka na ziemi: posiadającego wielkie trzody i potężny majątek, teraz pracuje jako słu-

53 Ibidem.

54 Na temat techniki przekładu, która zakładała znajomość pozostałej części Księgi zob.: H. Heater Jr., A Septuagint Translation Technique in the Book of Job, s. 32-33.

55 Na temat tych tekstów: ibidem, s. 33-34.

56 Ibidem, s. 31 oraz 35-36. 
żąca - w kulturze Bliskiego Wschodu musiał to być wyjątkowo mocny obraz, który zresztą potem tak bardzo rozwinie Testament Hioba.

Czytając grecki tekst Hi można oczywiście żonie Hioba zarzucić egoizm i fakt, że nie pocieszyła cierpiącego męża i nie rozumiała jego wytrwałej postawy w tym, co ich spotkało ${ }^{57}$, ale jednocześnie trzeba pamiętać, że tak jak i Hiob, także i ona nie wiedziała dlaczego spadły na nich wszystkie ciężkie próby - bowiem zarówno Hiob, jak i jego żona, nie byli świadkami scen „w niebie przed tronem Boga".

Dopiero po ukazaniu tego kontekstu na końcu padają słowa żony do Hioba, które tak mocno brzmiały w tekście hebrajskim: „Ale powiedz jakieś słowo

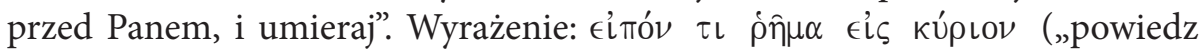
jakieś słowo przed Panem") nie jest aż tak mocne jak eufemistyczne hebr. wyrażenie: ברּרךּ אלדִים (,złorzecz Bogu”). A cała wypowiedź żony ukazana jest w nowym świetle - już nie jako gwałtowny atak na cierpiącego męża, ale jako słowa bezsilności kobiety, która sama cierpi. W tekście hebrajskim nie było mowy o jej cierpieniu, tekst grecki stara się na ten wątek uwrażliwić.

Także odpowiedź Hioba z 2,10 jest jakby łagodniejsza. W BH mówił: „Mówisz jak jedna z głupich. Skoro dobro przyjęliśmy od Boga, to zła nie przyjmiemy?”, a narrator dodawał: „W tym wszystkim nie zgrzeszył Hiob wargami”, jakby chwaląc Hioba za jego postawę wobec tej ostatniej pokusy, ze strony jego żony. Tekst LXX z kolei całą i tę wypowiedź jakby uspokoi, iż wyda się mniej gwałtowna: Czytamy: „On zaś [=Hiob] popatrzywszy, powiedział jej: „Powiedziałaś jak jedna z nierozumnych kobiet. Skoro dobre [rzeczy] przyjęliśmy $\mathrm{z}$ ręki Pana,[to czy] złych nie przetrwamy? W tych wszystkich rzeczach, które przyszły na niego, nie zgrzeszył Hiob wargami przed Panem.”

Odpowiedź Hioba nie jest więc atakiem na zachęcającą go do grzechu żonę, ale Hiob patrzy (na nią? w niebo ${ }^{58}$ - tego wątku tekst hebrajski nie miał) i spokojnie odpowiada, zachęcając także i ją do wytrwałości, którą sam posiadał. Nie nazywa jej jedną z głupich, używając tam tego mocnego słowa (jakim został w BH nazwany człowiek uważający, że nie ma Boga w Ps 14 i 53), ale używa bardziej spokojnego wyrażenia ,jedna z nierozumnych kobiet”. W słowach Hioba jest cierpliwość dla żony. Także słowa narratora $\mathrm{z}$ końca tego wersetu nie są jedynie pochwałą Hioba za tę wytrwałość przeciw pokusie żony, ale wyraźnie LXX podkreśli, iż Hiob nie zgrzeszył „we wszystkim co na niego spadło” (a nie tylko w tym ostatnim momencie słów żony i reakcji na nie). Na końcu pojawia się jeszcze ważny dodatek: LXX dodaje, że Hiob nie zgrzeszył „przed Panem”,

57 J. Cook, Are the Additions in Job 2,9a-e to Be Deemed as the Old Greek Text?, Biblica 91/2010, s. 280.

58 Na temat tego spojrzenia Hioba, zob.: ibidem, s. 278. 
czego nie posiadał tekst hebrajski - nie chodzi bowiem o grzech w oczach innych, czy o grzech jakikolwiek, ale grzech, którego ocenę i osąd może wydać jedynie Bóg. Hiob przed Panem pozostał bez grzechu ${ }^{59}$.

Przez wieki interpretacji tego fragmentu zastanawiano się, jaki charakter ma ta dłuższa wypowiedź żony Hioba. Czy odpowiedzialne za nią jest inne hebrajskie Vorlage tego tekstu, czy może tłumacz LXX, który chciał rozbudować wątek żony w Prologu. A może został on dodany do Księgi później, w czasie jednej z rewizji tekstu? A może, jak mówili komentatorzy (np. A.B. Davidson), tłumacz (lub redaktor) Księgi znał lepiej kobiety i wiedział, że w takiej trudnej sytuacji, jaka spotkała Hioba, a także jego żonę, kobieta nie poprzestałaby na wypowiedzeniu tylko jednego zdania ${ }^{60}$. Jaki jest zatem charakter tego dodatku?

$\mathrm{Na}$ ten temat wypowiedział się G. Beer, który pod koniec XIX w. wysunął hipotezę, że u jego podstaw leży midrasz semicki - hebrajski lub aramejski -powstały jeszcze jako dodatek do tekstu hebrajskiego, by rozwinąć lament $\dot{z ̇ o n y}^{61}$. Tę hipotezę podtrzymał także F. Horst ${ }^{62}$. Jednak badania językowe, prowadzone m.in. przez H. Heatera, ukazały, że dodatek ten nie może mieć semickiego podłoża, ze względu na występujące $\mathrm{w}$ nim terminy ${ }^{63}$. Nie wskazuje na nie także żaden znaleziony choćby fragmentarycznie przykład poszerzonego hebrajskiego tekstu ${ }^{64}$. Nie posiada takiej poszerzonej wypowiedzi żony Hioba także żadna inna $\mathrm{z}$ wersji starożytnych. To, co możemy powiedzieć z pewno-

59 Na temat tej odpowiedzi Hioba zob. także H. Heater Jr., A Septuagint Translation Technique in the Book of Job, s. 36-37; G. Gerleman, Studies in the Septuagint. I: Book of Job, Lund 1946, s. 58-59.

60 A.B. Davidson, A Commentary, Grammatical and Exegetical on the Book of Job with a Translation, t. 1, London 1862, cyt. za: S.R. Driver, G.B. Gray, A Critical and Exegetical Commentary on the Book of Job Together with a New Translation, Edinburgh 1921, s. 25; por. H. Heater Jr., A Septuagint Translation Technique in the Book of Job, s. 31.

61 G. Beer, Der Text des Buches Hiob Erstes Heft. Kapitel I-XIV, Marburg 1895, s. 11; por. M. Witte, The Greek Book of Job, w: Das Buch Hiob und seine Interpretationen, s. 42-43.

62 F. Horst, Hiob, t. 1. Teilband, Biblischer Kommentar: Altes Testament 16/1, Neukirchen-Vluyn 1968, s. 22; por. M. Witte, The Greek Book of Job, w: Das Buch Hiob und seine Interpretationen, s. 43.

63 Por. H. Heater Jr., A Septuagint Translation Technique in the Book of Job, s. 31-36.

64 M. Witte dodaje, że w zasadzie w całej greckiej Księdze Hioba możemy mieć pewność, że za zmiany nie było odpowiedzialne inne Vorlage, a podstawowym argumentem jest według niego fakt wzrastania liczby braków i zmian w miarę lektury Księgi. Braki i zmiany pojawiają się także w szczególnie trudnych momentach tekstu hebrajskiego i wchodzą w konflikt ze strukturą poetycką tekstu, co daje podstawę przypuszczać, że pochodziły jednak od samego tłumacza (M. Witte, The Greek Book of Job, w: Das Buch Hiob und seine Interpretationen, s. 37). 
ścią, że tekst ten jest oryginalną lekcją LXX, pozostaje jednak pytanie, kto jest za ten dodatek odpowiedzialny: sam tłumacz, czy późniejsi redaktorzy tekstu?

Badania krytyki tekstualnej ukazują, że wszystkie manuskrypty LXX Hi posiadają tekst dodatku ${ }^{65}$. Podobnie, jak i pozostałe wersje wywodzące się z greckiego tekstu (tłumaczone za LXX) oddają dłuższą wypowiedź żony Hioba: wersja sahidzka, etiopska, arabska ${ }^{6}$. Czasami kodeksy i inne rękopisy, mając dodatek słów żony Hioba, różniły się w tekście dodatku między sobą. Są to jednak zmiany drobne i nie zmieniające sensu tekstu ${ }^{67}$; w większości dotyczą dodania przyimków, czy zmiany formy z rzeczownikowej na imiesłowową ${ }^{68}$.

Ciekawe, że późniejsze rewizje tekstu LXX, przekłady Aquili i Teodocjona, a także Symmacha, usuwają dodatek LXX, pozostawiając w swoich przekładach wersję wierną tekstowi hebrajskiemu ${ }^{69}$, zgodnie z zasadą literalnej wręcz wierności tekstowi hebrajskiemu, jak i niejednokrotnie wierności zasadzie odcinania się od interpretacji dokonanej przez samą $\mathrm{LXX}^{70}$.

65 Najważniejsze dla badań LXX Hi kodeksy zaznaczają ten tekst obelusem, jako dodatek. Czyni tak Syrohexapla, Kodeks Colbertinus i Kodeks 255 (por. F. Field, Origenis Hexaplorum que supresunt; sive veterum interpretum graecorum in totum Vetus Testamentum fragmenta, t. II: Jobus, Oxford 1875, s. 7). Natomiast pierwotnym przekładzie Hieronima, który normalnie zaznaczał zmiany między tekstem hebrajskim, a greckim, błędnie pominięto obelus (choć sam dodatek zawarty jest w tekście); por. P. Dhorme, Le Livre de Job, s. 18.

66 P. Dhorme, Le Livre de Job, s. 18.

67 Por. Septuaginta. Vetus Testamentum Graecum. Auctoritate Academiae Scientiarum Gottingensis editum, t. XI, 4 Iob, red. J. Ziegler, Göttingen 1982, ad loc.

68 Np. wśród kodeksów majuskułowych różnicę odnotowuje Kodeks Aleksandryjski, który na początku w. 9 posiada lekcję $\tau \omega$ I $\omega \beta$ („Hiobowi”) w miejsce popieranej przez inne

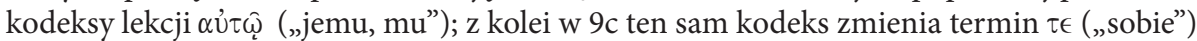

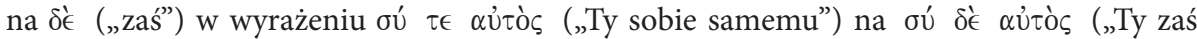

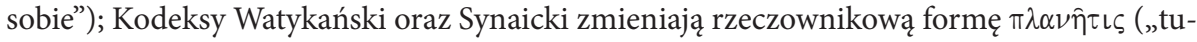
łaczka”) na imiesłowową od $\pi \lambda \alpha \nu \alpha ́ \omega$ („błąkać się”), a Kodeks Watykański w 9d dodaje po

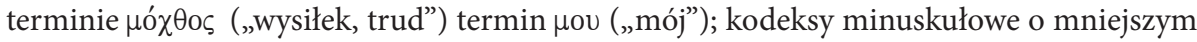
znaczeniu, u Zieglera zaznaczone numerami 137-680, pomijają termin пo $\lambda \lambda$ ov̂ - zostawia-

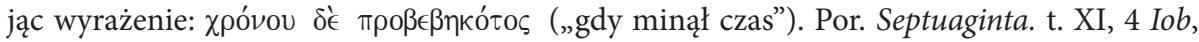
red. J. Ziegler, ad loc.

69 Por. F. Field, Origenis Hexaplorum que supresunt; sive veterum interpretum graecorum in totum Vetus Testamentum fragmenta, t. II: Jobus, Oxford 1875, s. 7.

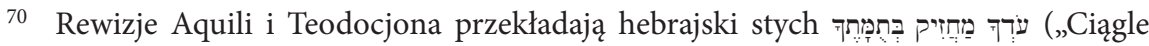

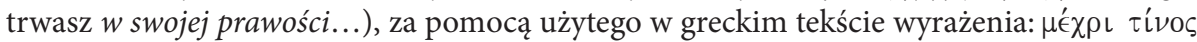

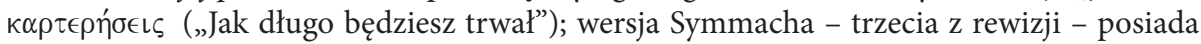

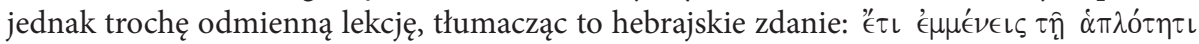
бou (,jeszcze zachowujesz swoją prostotę/ jedność”; por. F. Field, Origenis Hexaplorum, t. II: 
Zastanawiając się nad charakterem tego dodatku w LXX, niektórzy badacze (np. H. Heater Jr., N. Fernández Marcos) wysunęli hipotezę, że nawet dla samej LXX Hi tekst ten jest wtórny - dodany później, że nie jest on dodatkiem samego tłumacza, ale dodanym jeszcze później, w efekcie rewizji o tendencjach midraszujących, które powstały w obszarze języka greckiego ${ }^{71}$. Wskazywać by miało na to przede wszystkim użyte w wypowiedzi żony w LXX słownictwo, które odróżnia dodatek od pozostałej części przekładu LXX Hì ${ }^{72}$. Pojawiają się w nim rzadko występujące słowa, jak np.: $\lambda \alpha$ ‘́

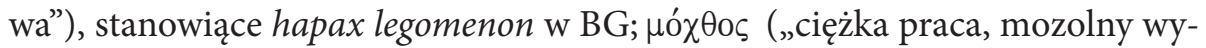
siłek"), typowy dla Koh w LXX, ale w Hi rzadki - występujący tylko dwukrotnie

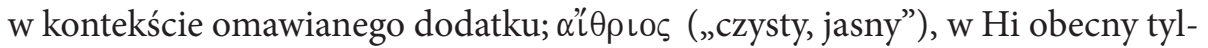
ko tu; $\delta\llcorner\alpha \nu \cup \kappa \tau \in \rho \in \cup \in \in \nu \nu$ (czasownik oznaczający „spędzić całą noc"), stanowiący hapax legomenon w LXX (pojawi się on jeszcze raz w NT w Łk 6,12 o cało-

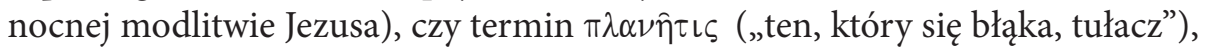
hapax legomenon w całej Biblii Greckiej. Jednak hapax legomena pojawiają się na przestrzeni całej LXX Hi - tłumacz grecki, podobnie, jak i w oryginale hebrajskim - używa bardzo wielu słówek nieznanych w Biblii, czy używanych rzadko. Być może więc i tu użył on po prostu oryginalnego słownictwa, które nawiązuje jednak do innych tego typu słów w LXX $\mathrm{Hi}^{73}$.

Z kolei M. Witte ukazywał, że wypowiedź żony Hioba w LXX nosi znamiona wpływu innych tekstów biblijnych - mogła zostać zmodyfikowana właśnie pod wpływem tych tekstów: zwłaszcza z Księgi Tobiasza (4,3-4), a także Księgi Rodzaju $(3,16)^{74}$. Także inni zauważają, że kompozycyjnie tekst z LXX Hi 2,9-10 przypomina scenę dialogu między Tobiaszem a jego żoną (Tob 2,13n;

Jobus, s. 7), wyrażając tymi innymi słowami tę samą myśl, która zawarta jest w TM, jeszcze bardziej odróżniając ją od LXX.

71 Por. H. Heater Jr., A Septuagint Translation Technique in the Book of Job, s. 31-36; zob. także N. Fernández Marcos, The Septuagint Reading of the Book of Job, w: The Book of Job, red. W.A.M. Beuken, Bibliotheca Ephemeridum Theologicarum Lovaniensium CXIV, Leuven 1994, s. 251-266 (zwł. s. 261); zob. także: D.J.A. Clines, Job 1-21, s. 53.

72 Zwracali na to uwage już S.R. Driver, G.B. Gray (A Critical and Exegetical Commentary on the Book of Job Together with a New Translation, Edinburgh 1921, s. LXXIII, przypis 16); ale i H. Heater Jr., A Septuagint Translation Technique in the Book of Job, s. 31-36; oraz J. Cook, Are the Additions in Job 2,9a-e to Be Deemed as the Old Greek Text?, Biblica 91/2010, zwł. s. 279-283.

73 Z takim rozumieniem opowiedział się J. Cook, który zbadał poszczególne słowa $\mathrm{i}$ ich analizę przedstawił $\mathrm{w}$ tekście, w którym przypisuje pochodzenie dodatku samemu tłumaczowi: Are the Additions in Job 2,9a-e to Be Deemed as the Old Greek Text?, Biblica 91/2010, zwł. s. 279-283.

74 M. Witte, The Greek Book of Job, w: Das Buch Hiob und seine Interpretationen, s. 43. 
$5,18-22 ; 10,4-7)^{75}$. Czy jednak sam tłumacz nie mógł korzystać $\mathrm{z}$ tych znanych mu tekstów?

W takiej sytuacji trzeba zadać także pytanie: kto miałby dokonać ew. rewizji? I kiedy? Orygenes sam nie mógł tego zrobić, bo przedstawił już tekst z dodatkiem, zaznaczając nawet, że jest to dodatek tłumacza; mówi o nim w punkcie 3 wspomnianego Listu do Juliusza Afrykańczyka ${ }^{76}$. Ponadto wcześniej ta nowa interpretacja wystapienia żony Hioba musiała być znana twórcom Testamentu Hioba, apokryfu, który powstał na przełomie I w. przed Chr. i I w. po Chr., w Aleksandrii (zatem w tym samym środowisku, co LXX), i - jak zostanie ukazane dalej - oparł swoją interpretację postaci, a nawet rozwijając jej wątek - na podstawie tekstu LXX, który musiał znać z dodatkiem. Chyba, że to autorzy apokryfu mieli by ten dodatek dołączyć do treści Księgi, wcześniej rozwinąwszy jej wątek w swoim tekście ${ }^{77}$. Wydaje się to zbyt skomplikowane.

W związku z tym inni (np. C.E. Cox, J. Cook, a dawniej H.B. Swete) dodatek słów żony Hioba interpretowali właśnie jako pracę samego tłumacza $\mathrm{LXX}^{78}$, który wydłużył tekst jej wypowiedzi. Mogło być tak, że tłumacz rzeczywiście uznał wypowiedź żony Hioba w TH za niewystarczającą. Było to możliwe, tym bardziej że jak zostało zaznaczone, miał dość swobodne podejście do tekstu, który tłumaczył. Mogło także być tak, że dał on tu wyraz tendencjom midraszującym, które występowały w innych miejscach LXX, a które polegały na rozwijaniu ról mniej znaczących bohaterów ksiąg - a takim bohaterem drugoplanowym niewątpliwie była żona Hioba ${ }^{79}$. Mógł to zrobić pod wpływem innych Ksiąg (Rodzaju, Tobiasza), znając także treść Księgi Hioba i problemy $\mathrm{z}$ jej interpretacją.

75 M. Kepper, M. Witte, Job/Das Buch Ijob/Hiob, w: Septuaginta Deutsch. Erläuterungen und Kommentare zum griechischen Alten Testament. Band II: s. 2041-2126; zob. także M. Witte, The Greek Book of Job, w: Das Buch Hiob und seine Interpretationen, s. 43.

76 Orygenes, Epistola ad Africanum 3; PG 11, k. 47-86; La Lettre à Africanus sur l'histoire de Suzanne, SC, t. 302, s. 469-578. Wynika z tego tekstu, że dodatek słów żony Hioba

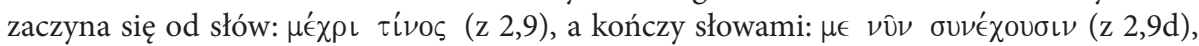
z kolei wyrażenie $\dot{\alpha} \lambda \lambda \dot{\alpha} \epsilon i$ ก́ó („ale rzekł”, z 2,9e) ma rozpoczynać na nowo przekład tekstu hebrajskiego; por. także P. Dhorme, Le Livre de Job, s. 18.

77 Por. J. Cook, Are the Additions in Job 2,9a-e to Be Deemed as the Old Greek Text?, s. 282.

78 Por. C.E. Cox, Iob. To the Reader, w: A New English Translation of the Septuagint. And the Other Greek Translations Traditionally Included under that Title, red. A. Pietersma, B.G. Wright, New York - Oxford 2007, s. 667-668; J. Cook, Are the Additions in Job 2,9a-e to Be Deemed as the Old Greek Text? s. 275-284; H.B. Swete, An Introduction to the Old Testament in Greek, 1902, wyd. uzupełnione: R.R. Ottley, New York 1968, s. 256.

79 P. Dhorme, Le Livre de Job, s. 18. 
Niezależnie od tego, czy uznamy tekst dodatku za dzieło tłumacza, czy też efekt późniejszej rewizji, rzuca on nowe światło na rozumienie postaci żony Hioba. W zaznaczonych zmianach, niezależnie od tego, kto jest za nie odpowiedzialny, widać troskę, by zrozumieć całość tej historii poprawnie. Nowe rozrysowanie bohaterów, ich wypowiedzi i zachowań, świadczy o tym, że tłumacz (lub redaktor) miał wyraźnie własny pomysł na Księgę.

Wątek cierpiącej żony z LXX jeszcze bardziej będzie rozwinięty we wspomnianym już apokryfie - w Testamencie Hioba, który żonę ukarze jako cierpiącą, a nawet miłosierną względem swego męża. Apokryf ten najwyraźniej oparty jest na tekście LXX, a nie na BH i jest to pierwsze, najstarsze znane świadectwo interpretacji nie $\mathrm{BH}$ ale LXX.

\section{Żona Hioba w Testamencie Hioba}

Testament Hioba to pismo apokryficzne, które ,jest dokumentem przedstawiającym historię biblijnego Hioba w sposób upiększony i barwny, a niekiedy humorystyczny, uwydatniając przy tym cnotę wytrwałości” ${ }^{80}$. Na temat samego apokryfu napisano wiele ${ }^{81}$. Jego tekst zachowany jest w czterech manuskryptach, które szerzej znane są od XIX w. ${ }^{82}$. Wiadomo dziś, że został napisany po grecku (upadły teorie o jego semickim pochodzeniu ${ }^{83}$ ), i ,jest owocem religijności i twórczości literackiej Żydów mieszkających w diasporze" ${ }^{84}$, najpewniej diasporze w Egipcie, o czym świadczy oparcie tekstu na parafrazującym grec-

80 W. Linke, Testament Hioba, w: Pisma apokaliptyczne i Testamenty, red. M. Parchem, Apokryfy Starego Testamentu, pod redakcją Zdzisława J. Kapery i Stanisława Mędali t. 2, Kraków-Mogilany 2010, s. 341.

81 Najważniejsze wydania tekstu: The Testament of Job According to the SV Text, red. R. A. Kraft et al., Pseudepigrapha Series 4, Missoula, Montana 1974. W Polsce istnieją dwa opracowania tekstu: W. Linke, Testament Hioba, w: Pisma apokaliptyczne i Testamenty, red. M. Parchem, s. 341-392 oraz A. Tronina, Testament Joba, w: Zmartwychwstat prawdziwie, red. A. Paciorek, A. Tronina, P. Łabuda, Tarnów 2010, s. 519-548. Por. także: A. Tronina: „Testamentum Iobi” i początki mistyki Merkaby, w: Apokaliptyka wczesnego judaizmu i chrześcijaństwa, red. M. S. Wróbel, Lublin 2010, s. 143-154. Dalsza bibliografia dot. tego apokryfu zob.: W. Linke, Testament Hioba, w: Pisma apokaliptyczne i Testamenty, red. M. Parchem, s. 350-352.

\footnotetext{
82 Por. ibidem, s. 341.

83 Por. ibidem, s. 344.

84 Ibidem.
} 
kim przekładzie Księgi Hioba w LXX ${ }^{85}$, a także wątki egipskie pojawiające się w jego tekście - jak choćby przypisanie Hiobowi godności króla całego Egiptu (TestHi 28,7$)^{86}$. Tekst apokryfu mógł powstać w I w. przed lub I w. po Chr. ${ }^{87}$ Jeśli uznać powstanie LXX Hi ok. 150 r. przed Chr., pisma te dzieli ok. 150 lat.

Wątek żony w Testamencie Hioba zajmuje naprawdę dużo miejsca w porównaniu $\mathrm{z}$ tekstem hebrajskim samej Księgi Hioba, a nawet $\mathrm{z}$ jego tekstem greckim zawartym w LXX. Nie tylko jest w nim wydłużona jej wypowiedź, ale także ukazany jej trudny kontekst, w którym słowa żony można zupełnie inaczej zrozumiećc ${ }^{8}$. Apokryf podaje wiele szczegółów dotyczących bohaterki, choćby jej imię: Sitis (Sitida) ${ }^{89}$, pochodzące albo od określenia „nosząca chleb"90, albo prawdopodobniej od nazwy krainy, z której pochodził Hiob w LXX: Ausitis (LXX Hi 1,1).

Apokryf w swojej dużej części złożony jest $\mathrm{z}$ wypowiedzi samego Hioba, opowiadającego swoją historię. Fragmenty dotyczący żony zajmują w nich naprawdę dużo miejsca. Opowieść o niej rozpoczyna się w rozdz. 21 i trwa nieprzerwanie do rozdz. 26, które poniżej zostaną zaprezentowane (w przekładzie W. Linkego):

85 Na ten temat zob. zwłaszcza: J. Dochhorn, Das Testament Hiobs als exegetischer Text. Ein Beitrag zur Rezeptionsgeschichte der Hiob-Septuaginta, w: Die Septuaginta: Texte, Theologien, Einflüsse, t. 2: Internationale Fachtagung veranstaltet von Septuaginta Deutsch (LXX.D), Wuppertal 23.-27.7.2008, red. W. Kraus, M. Karrer, M. Meiser, Wissenschaftliche Untersuchungen zum Neuen Testament 252, Tübingen 2010, s. 671-688; B. Schaller, Das Testament Hiobs und die Septuaginta-Übersetzung des Buches Hiob, Biblica 61 (1980), s. 337-406; M. Witte, The Greek Book of Job, w: Das Buch Hiob und seine Interpretationen, s. 43.

86 W. Linke, Testament Hioba, w: Pisma apokaliptyczne i Testamenty, red. M. Parchem, s. 344 .

87 Ibidem, s. 345-346.

88 Por. J. Dochhorn, Das Testament Hiobs als exegetischer Text, s. 682-683; oraz wcześniejsze opracowania: P.W. van den Horst, Images of Women in Testament of Job, w: Studies in the Testament of Job, red. M.W. Knibb, P.W. van de Horst, Cambridge 1989, s. $93-$ 116; S.R. Garret, The "Weaker Sex" in the Testament of Job, Journal of Biblical Literature 112 (1993)1, s. 55-70; M.C. Legaspi, Job's Wives in the Testament of Job: A Note on the Synthesis of Two Traditions, Journal of Biblical Literature 127/2008, s. 71-79. Zob. także: S.E. Balentine, Job, Smyth \& Helwys Bible Commentary, Macon, Georgia 2006, s. 64.

89 O imieniu i jego formach w rękopisach Testamentu Hioba, zob. W. Linke, Testament Hioba, w: Pisma apokaliptyczne i Testamenty, red. M. Parchem, s. 370, przyp. 215.

90 M. Witte, The Greek Book of Job, w: Das Buch Hiob und seine Interpretationen, s. 43. 
TestHi 21,1-4:

I spędziłem czterdzieści osiem lat na kupie gnoju poza miastem z powodu plag, w ten sposób jak widziałem na własne oczy moje dzieci, moją pierwszą (dwa rękopisy apokryfu mają: „poniżoną" ${ }^{11}$ ) żonę noszącą wodę w domu bogaczy jak służąca, dopóki nie dostała pożywienia i nie przyniosła mi. A ja przejęty mówiłem: „O arogancjo władców tego miasta! Jakże to hańbicie moją małżonkę jako niewolnicę? Potem powróciłem do cierpliwej postawy" ${ }^{92}$.

\section{I dalej, TestHi 22,1-3:}

Po jedenastu latach, gdy zabrano jej możliwość przynoszenia pożywienia dla mnie, ledwie pozwalając jej zarabiać na własne pożywienie. A ona, otrzymawszy, dzieliła między siebie i mnie, powiedziawszy z bólem: „Biada mi, wkrótce może nie wystarczyć pożywienia. I nie powstrzymała się przed pójściem na rynek prosić o chleb u sprzedawców chleba, dopóki nie przyniosła mi i jadłem"93.

Dalej w historii żony pojawia się szatan, TestHi 23,1-11:

Dowiedziawszy się o tym szatan zamienił się w sprzedawcę (dwa rękopisy dodają: sprzedawcę chleba ${ }^{94}$ ). I stało się, że przypadkiem poszła do niego moja żona i prosiła o chleb, sądząc, że jest on człowiekiem. I szatan powiedział jej: „Uiść cenę i weź, co chcesz”. Odpowiedziawszy zaś, mówi mu: „Skąd mam wziąć pieniądze? Nie wiesz, jakie złe rzeczy na nas spadły? Jeśli więc zechciałbyś się ulitować, ulituj się, jeśli nie, to ty zobaczysz”. I odpowiedział jej mówiąc: „Jeśli nie bylibyście godni złych rzeczy, to byście ich nie otrzymali. Teraz więc jeśli nie masz w twojej ręce pieniędzy, połóż mi włosy z Twojej głowy i weź trzy chleby. Być może będziecie w stanie przeżyć przez trzy dni”. Wtedy powiedziała do siebie: „Co mi po włosach głowy w zestawieniu z moim głodnym mężem?” I tak wzgardziwszy włosami swej głowy, powiedziała mu: „Zgoda, bierz je”. Wziąwszy nożyczki obcięła włosy swej głowy. I dał jej trzy chleby a wszyscy na to patrzyli. Ona wziąwszy, przyszła i dała mi. A szatan szedł za nią drogą, krocząc za nią ukradkiem i zwodził jej serce ${ }^{95}$.

Dopiero po tym opisie zostaje przedstawiona - także rozbudowana - scena, którą znamy z biblijnej historii Hioba, kiedy jego żona przychodzi do nie-

91 W. Linke, Testament Hioba, w: Pisma apokaliptyczne i Testamenty, red. M. Parchem, s. 368, przyp. 191.

92 Ibidem, s. 368.

93 Ibidem, s. 368.

94 Ibidem, s. 368, przyp. 196.

95 Ibidem, s. 368-369. 
go; wypowiedź jest szerokim cytatem wersji Hi 2,9 zawartej w LXX; TestHi 24,1-10:

Wtedy zbliżyła się moja żona i krzyknąwszy z płaczem, mówi do mnie: „Hiobie, Hiobie, dokąd będziesz siedział na kupie gnoju poza miastem myśląc: jeszcze trochę i wyglądając nadziei swego zbawienia? A ja przechodzę jako służąca $\mathrm{z}$ jednego miejsca na drugie. Dlatego przepadła pamięć o tobie: synowie moi i córki moich wnętrzności, (dla) których na próżno trudziłam się z mozołem. Ty zaś siedzisz w zgniliźnie robaków spędzając noc pod gołym niebem. A ja znowu trudzę się bardzo nieszczęśliwa (całymi) dniami i nocą, dopóki nie zdolam przynieść ci pożywienia. Ledwie dostaję pożywienia dla siebie i dzielę je między ciebie i siebie. Zastanawiam się w swym sercu, że nie dość ci, ze cierpisz, ale nie możesz nasycić się pożywieniem. Tak, że odważyłam się bezwstydnie iść na rynek. Jeśli przebite zostało moje serce, bo nie byłam w stanie kupić. Daj pieniądze i weź! Ja zaś ukazałam mu naszą trudność usłyszałam od niego: Jeśli nie masz, o kobieto, pieniędzy, połóż włosy twojej głowy i weź trzy chleby. Może przeżyjecie przez trzy dni. A ja załamawszy się pod wpływem nieszczęść, powiedziałam mu: Zgadzam się na to. Nożyczkami bez szacunku obciął mi włosy na rynku, w otoczeniu zdziwionego tłumu" ${ }^{\prime \prime}$.

Następnie tekst przedstawia zdziwienie tych, którzy patrzyli na Sitis, dawniej bogatą, dziś w zupełnie innej sytuacji. Jak refren będą powtarzały się słowa: „teraz zamienia swoje włosy na chleby”. Na końcu tego fragmentu pojawią się te najbardziej gorzkie słowa żony Hioba; TestHi 25,1-10:

Kto nie zdziwił się, że ona jest Sitida, żona Hioba? Ta, która miała przedpokój z nakrytymi czternastoma progami i drzwi wewnątrz drzwi, (gdzie czekało się) tak długo aż wreszcie ktoś zostałby uznany godnym bycia wprowadzonym do niej, teraz zamienia swoje włosy na chleby. Ta, której wielbłądy przenosiły dobra dla biednych w (różnych) krainach, teraz zamienia swoje włosy na chleby. Zobacz, mająca siedem nieruchomych stołów w domu, przy których jedli biedni i każdy cudzoziemiec, teraz odsprzedaje włosy za chleby. Patrz, ta, która miała naczynia do mycia stóp ze złota i ze srebra, teraz stopami chodzi po kurzu. Zobacz, to jest ta, która miała odzienie z delikatnego lnu tkanego ze złotem, teraz nosi połatane (ubranie) i zamieniła włosy na chleby. Patrzcie na tę, która miała łoża ze złota i ze srebra, teraz sprzedała włosy za chleby. „Ogólnie, Hiobie, Hiobie, mając wiele rzeczy do powiedzenia, mówię Ci jednak krótko: z powodu słabości mojego serca kruszą się moje kości. Powstań ty biorąc chleby, bądź syty i powiedz jakieś słowo przeciw Panu i umrzyj. Ja zaś uwolnię się od załamania z powodu cierpienia Twojego ciała"97. 
Także odpowiedź Hioba na słowa żony jest rozbudowana i ukazująca ją w zupełnie innym świetle; TestHi 26,1-6:

A ja odpowiedziałem jej: „Oto siedemnaście (jeden manuskrypt: siedem ${ }^{98}$ ) znoszę plagi, poddany robakom w moim ciele, a nie ociężała dusza moja z powodu cierpień tak wielkich, jak podczas gdy powiedziałaś: powiedz jakieś słowo przeciw Panu i umrzyj. Długo znoszę to i ty znosisz zagładę naszych dzieci i posiadłości, chcąc byśmy powiedzieli coś przed Panem, gdyż zostaliśmy pozbawieni tak wielkiego bogactwa. Dlaczego więc nie są wspomniane tak wielkie dobra, w które byliśmy zasobni? Skoro te dobra przyjęliśmy z ręki Pana, czemu rzeczy złych znowu mielibyśmy nie znieść. Ale zachowajmy cierpliwość dopóki Pan ulituje się miłosiernie nad nami. Teraz czy nie widziałaś diabła stojącego za tobą i niepokojącego twoje myśli tak, że nawet ja zbłądziłem? Chce bowiem ukazać ciebie jako jedną z kobiet nierozumnych zwodzących prostolinijność swych mężów"99.

Po tym opisie następuje jeszcze rozmowa Hioba z szatanem - Hiob wzywa szatana, by się ujawnił, a nie szedł w ukryciu za jego żoną. Szatan uznaje prawość Hioba i wręcz podziw dla jego wytrwałości (TestHi 27,1-7) i odstępuje od Hioba na trzy lata, po nich pojawiają się u Hioba przyjaciele - ostatnia plaga, jaka spada na Hioba.

Znamienne jak bardzo aleksandryjski apokryf zmienia wizerunek żony Hioba i samego Hioba, podkreślając cierpliwość i wytrwałość obojga. Rozbudowuje także i zmienia rolę żony Hioba ${ }^{100}$. Podkreśla to fakt, że zanim żona Hioba przemówiła do niego, Hiob siedział na kupie gnoju przez wiele lat! W TestHi 21,1 mowa jest aż o 48 latach!, nieco dalej (TestHi 22,1 ) o 11 latach, sam Hiob mówi o 17 latach (TestHi 26,1), które Hiob siedział „poza miastem na kupie gnoju”, podczas gdy jego żona musiała pracować jako niewolnica by go utrzymać. W takim nowym kontekście jawi się ona nie jako gwałtowna „pomocnica diabła”, ale - podobnie jak Hiob - wzór cierpliwości i wytrwałości w cierpieniu! Nawet poniekąd dzielniejsza niż sam Hiob!, bo zdolna wyżywić siebie i jego ta, która wcześniej opływała we wszelkie bogactwa.

Jej pracowitość i poniżenie, jakiego doznała w zaistniałej dla nich obojga nowej sytuacji, zwłaszcza fakt pracy jako niewolnica, a potem oddania nawet swoich włosów, co w kulturze Bliskiego Wschodu musiało brzmieć wyjąt-

98 Ibidem, s. 371, przypis 226.

99 Ibidem, s. 371-372.

100 Testament Hioba w ogóle kobietom poświęca znacznie więcej miejsca; zwraca uwagę na to: S.R. Garret, The "Weaker Sex" in the Testament of Job, Journal of Biblical Literature 112 (1993) 1, s. 56. 
kowo mocno (było także symbolem żałoby ${ }^{101}$ ), stały się powodem nie tylko usprawiedliwienia jej słów do Hioba, ale wręcz zrozumienia jej cierpienia. Jak refren wielokrotnie powtarzają się słowa o wcześniejszym bogactwie żony Hioba i tym, że „teraz odsprzedaje ona swoje włosy za chleb”.

Jedynym zarzutem, jaki kieruje do żony jej mąż, jest to, że nie doceniła ona dobrobytu z przeszłości, za który winna być wdzięczna Bogu (TestHi 26,4). Jednak za tę postawę żony tekst także obwini szatana, dostrzegając w nim głównego sprawcę zaistniałej sytuacji, który jednak zarazem sam przedstawia ją inaczej, według logiki, którą od początku prezentuje także w biblijnej Księdze Hioba, a która stała się przyczyną całej debaty o cierpieniu zawartej w Księdze. Mówi on do żony Hioba: „Jeśli nie bylibyście godni złych rzeczy, to byście ich nie otrzymali” (TestHi 23,6), sprowadzając myśli o winie na nich samych, którzy byli przecież od początku niewinni. Szatan jest tym, który sprowadza wątpliwości na żonę, a także na Hioba. Jednak jego podstęp zostaje odkryty i sam Hiob, jak i jego żona nie są oskarżeni o nic, ale stają się ofiarami szatańskiej intrygi. Żona także nie jest pomocnicą szatana, jak to można było odczytać $\mathrm{z}$ tekstu hebrajskiego, ale jest jego ofiarą, razem $\mathrm{z}$ mężem.

Obok tego kontekstu apokryf rozwija także jeszcze bardziej wypowiedź żony z LXX. Kiedy mówi ona słowa, poprzedzone gestami troski o swego męża, wypowiada je z czułością i pragnieniem ulżenia w cierpieniu swojemu mężowi. Słowa „złorzecz Bogu i umieraj” z tekstu hebrajskiego, czy greckie za LXX „powiedz jakieś słowo przeciw Panu i umieraj”, nie mają już wydźwięku negatywnego, ale są niejako chęcią wybawienia Hioba przed jego cierpieniami oraz chęcią wyswobodzenia siebie z cierpienia, jakie ono ze sobą niesie. Jak pisał jeden $\mathrm{z}$ komentujących ten fragment: „Żona Hioba $\mathrm{z}$ «Testamentu» nie jest już obcym człowiekiem pogardzającym swoim fanatycznym mężem. Ona współcierpi z nim. Nie pozostawia go samego. Dla niego gotowa jest do wstydu i pohańbienia"102.

Zresztą za tę swoją postawę zostaje nagrodzona „pogodną śmiercią” (TestHi 40,6$)^{103}$. Apokryf opisuje koniec jej życia w rozdz. 39-40. Jest to jeden z piękniejszych wyrazów szacunku dla tej kobiety, która cierpiała wraz z mę-

101 Por. W. Linke, Testament Hioba, w: Pisma apokaliptyczne i Testamenty, red. M. Parchem, s. 369, przyp. 203.

102 P. Śpiewak, Żona Hioba, Tygodnik Powszechny, nr 11 (3323), z dn. 17 marca 2013.

103 W. Linke, Testament Hioba, w: Pisma apokaliptyczne i Testamenty, red. M. Parchem, s. $381-382$. 
żem. Nazwana jest tam pośmiertnie „kobietą godną czci i chwały”104 (TestHi 40,13), za czyny, których dokonała, napisano jej pieśń żałobną, i choć Sitis, według apokryfu, nie dała Hiobowi już więcej dzieci - urodzą się one z innej kobiety - to wpisała się do szeregu mężnych niewiast znanych z dziejów biblijnych. P.W. van der Horst dostrzeże w tym obrazie żony Hioba z Testamentu Hioba wypełnienie poematu o dzielnej niewieście z Prz $31^{105}$.

Pojawia się tu zatem trzeci portret żony Hioba. Od „współpracownicy diabła” w tekście hebrajskim, przez współczującą i żaląca się na własny los w LXX, po współczującą Hiobowi i troszcząca się o jego wyzwolenie od cierpienia w Testamencie Hioba.

Wszystkie te portrety są konsekwencją interpretacji tekstów kolejno z siebie wynikających: Biblii Hebrajskiej zinterpretowanej w przekładzie LXX oraz tekstu LXX zinterpretowanego w aleksandryjskim apokryfie, który próbował połączyć wszystkie tradycje w jedną zrozumiałą całość. Jest to jeden z najbardziej wyraźnych przykładów tego, że tekst grecki Septuaginty stał się inspiracją jeszcze dalej idącej interpretacji w pobożnościowej literaturze żydowskiej. Ukazują one jak istotną rolę odgrywał przekład z Aleksandrii w kształtowaniu pobożności i mentalności.

Czy te trzy obrazy żony Hioba znalazły swoje odzwierciedlenie w literaturze późniejszej? I tak, i nie ${ }^{106}$. Z jednej strony zgodnie z tekstem biblijnym (BH i LXX) jednak to nie żonie Hioba Bóg ostatecznie przyznał rację, i być może właśnie dlatego obraz "godnej czci” Sitis, zachowany w Testamencie Hioba nie został przyjęty szerzej $\mathrm{w}$ innych starożytnych interpretacjach tego tekstu. Z drugiej strony, obraz z Testamentu Hioba zainspiruje sposób myślenia

104 Ibidem, s. 382 (cały kontekst. rozdz. 39-40, zob. s. 380-382).

105 P.W. van den Horst, Images of Women in Testament of Job, w: Studies in the Testament of Job, red. M.W. Knibb, P.W. van de Horst, Cambridge 1989, s. 99 oraz 101; por. także: S.R. Garret, The "Weaker Sex" in the Testament of Job, Journal of Biblical Literature 112 (1993) 1, s. 55-57.

106 Por. M.C. Legaspi, Job's Wives in the Testament of Job: A Note on the Synthesis of Two Trwditions, Journal of Biblical Literature 127/2008, s. 71-79; a także: M. Witte, Hiob und Seine Frau in jüdischen Schriften aus hellenistische-römischer Zeit, w: H. Lichtenberger, U. Mittmann-Richtert, Biblical Figures in Deuterocanonical and Cognate Literature, Deuterocanonical and Cognate Literature Yearbook 2008, s. 355-394. Por. także: T. Klibengajtis, Hiobs Weib in der Exegese der lateinischen Kirchenväter. Ein Beitrag zur patristichen Frauenforschung, Analecta Cracoviensia 38-39 (2006-2007), s. 195-229. 
i rozumienia postaci żony Hioba, także w niektórych nurtach judaizmu rabinicznego, gdzie żona Hioba stanie się w jakimś sensie katalizatorem rozwoju swojego męża ${ }^{107}$, a także u Ojców Kościoła ${ }^{108}$, ale te wątki domagają się osobnego pogłębionego studium.

107 O tych nurtach: R. Gordis, The Book of God and Man: A Study of Job, Chicago 1965, s. 226. Por. także: B. Szwarcman-Czarnota, Błogosławić i przeklinać, Midrasz 137 (2008) 9.

108 Por. T. Klibengajtis, Hiobs Weib in der Exegese der lateinischen Kirchenväter, s. 195-229 . 
